Southern Methodist University

SMU Scholar

Faculty Journal Articles and Book Chapters

Faculty Scholarship

2012

\title{
The Missing Jury: The Neglected Role of Juries in Eighth Amendment Punishments Clause Determinations
}

Meghan J. Ryan

Southern Methodist University, Dedman School of Law

Recommended Citation

Megan J. Ryan, The Missing Jury: The Neglected Role of Juries in Eighth Amendment Punishments Clause Determinations, 64 FLA. L. REV. 549 (2012)

This document is brought to you for free and open access by the Faculty Scholarship at SMU Scholar. It has been accepted for inclusion in Faculty Journal Articles and Book Chapters by an authorized administrator of SMU Scholar. For more information, please visit http://digitalrepository.smu.edu. 


\title{
Florida Law Review
}

Founded 1948

\begin{tabular}{lll}
\hline \hline VOLUME 64 & MAY 2012 & NUMBER 3 \\
\hline \hline
\end{tabular}

\section{THE MISSING JURY: THE NEGLECTED ROLE OF JURIES IN EIGHTH AMENDMENT PUNISHMENTS CLAUSE DETERMINATIONS}

\author{
Meghan J. Ryan ${ }^{*}$
}

\begin{abstract}
A recent study of death penalty cases has revealed that judges, who are ordinarily thought of as the guardians of criminal defendants' constitutional rights, often impose harsher punishments than jurors. This may be unsettling in its own right, but it is especially concerning when one considers that judges are the individuals charged with determining whether punishments are unconstitutionally cruel and unusual under the Eighth Amendment and that these determinations are supposed to be based on society's evolving standards of decency. The study suggests that judges are out of step with society's moral norms, raising the question of why our justice system entrusts judges, rather than juries, with resolving questions of whether punishments are unconstitutionally cruel and unusual. This Article argues that juries are better equipped to make these determinations and that charging juries to employ their own moral values to decide these matters is more consistent with the underlying purpose and history of the ratification of the Eighth Amendment. This shift in power would also be in line with the Supreme Court's recent elevation of the jury in criminal cases such as Apprendi v. New Jersey and United States v. Booker.
\end{abstract}

INTRODUCTION 550

I. PUNISHMENTS Clause BACKGROUND 553

* Assistant Professor of Law, Southern Methodist University, Dedman School of Law. I thank Jeffrey Bellin, Douglas A. Berman, William W. Berry III, Sanjay K. Chhablani, Chad W. Flanders, John Inazu, Jeffrey Kahn, Corinna Barrett Lain, Michael J. Zydney Mannheimer, Dan Markel, Xuan-Thao Nguyen, Ryan W. Scott, John F. Stinneford, and participants at the Southeastern Association of Law Schools Annual Conference for their helpful comments, and I thank Natalie Cooley and Jessica Lamberth for their research assistance. I also thank the Michael C. and Jacqueline M. Barrett Endowed Faculty Research Fund and the Southern Methodist University Dedman School of Law for financial support. Finally, I thank Paul Pakidis and the Florida Law Review for their excellent editorial assistance. 


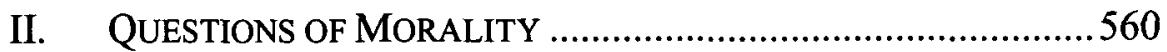

III. SIMILAR CONTEXTS, VARYING APPROACHES .......................564

IV. THE HISTORICAL ROLE OF THE JURY AND ITS DEMISE...........575

V. VIEWING EIghth Amendment CRuelty as a MiXed QUESTION OF LAW AND FACT ..............................................579

VI. ObVIOUS PRocedural HuRdLES......................................585

CONCLUSION 589

\section{INTRODUCTION}

Judges are ordinarily thought of as safeguarding the constitutional rights of social and political minorities. But research has demonstrated that, at least in the criminal context, judges can become conditioned to defendants' suffering ${ }^{1}$ and actually come down harder on criminal defendants than do juries. ${ }^{2}$ This result is exacerbated in jurisdictions in which judges are elected and thus often campaign on the ground that they are tough on crime. ${ }^{3}$ A recent and much-publicized example of judges' predispositions against criminal defendants in this context is Alabama judges' use of the state's jury-override system in capital sentencing. ${ }^{4}$ Under Alabama law, a jury determines whether a defendant convicted of a capital offense deserves the death penalty. ${ }^{5}$ The presiding judge, however, has the power to overrule the jury's conclusion and either impose the death penalty on the offender or demonstrate mercy and sentence the offender to life imprisonment instead. ${ }^{6} \mathrm{~A}$ recent study has revealed that, in $92 \%$ of cases in which Alabama judges overrode the jury's determination of whether capital punishment was justified, the judges used that power to impose capital punishment rather than a sentence of life imprisonment without parole.' These judges, then, are

1. See Jenia Iontcheva, Jury Sentencing as Democratic Practice, 89 VA. L. REV. 311, 353 (2003).

2. See Equal Justice Initiative, The Death Penalty in Alabama: Judge Override 14-16(2011), available at http://eji.org/eji/files/Override_Report.pdf.

3. See id.

4. See Adam Liptak, Overriding the Jury in Capital Cases, N.Y. TIMES, July 12, 2011, at A13.

5. See ALA. CODE $\S 13 A-5-46$ (1975).

6. See ALA. CODE $§ 13 A-5-47$ (e) (1975) ("While the jury's recommendation concerning sentence shall be given consideration, it is not binding upon the court.").

7. See The Death Penalty IN Alabama: Judge OVERride, supra note 2, at 14. This study examined the 107 cases of judicial override in Alabama between 1976 and 2011. See id. 
not functioning to protect criminal defendants from overzealous, revenge-hungry jurors as ordinarily thought. And Justice John Paul Stevens has stated that Alabama judges are not alone in imposing harsher punishments than juries; ${ }^{8}$ the effect is pervasive. ${ }^{9}$

Judges' tendencies to impose harsher punishments than jurors are concerning because judges are the individuals entrusted to protect criminal offenders from the cruel and unusual punishments proscribed by the Eighth Amendment. In making these determinations, judges often act as independent decisionmakers not beholden to the communities whose values the Eighth Amendment Punishments Clause is designed to reflect. Judges resolving issues of cruelty and unusualness purport to rely on punishment trends among the states, but judges have been accused of manipulating this data and instead imposing their own moral views on the rest of society by deciding which punishments are too cruel to be imposed on criminal offenders. Indeed, this lack of foundation for judges' Punishments Clause determinations is one of the central criticisms of this constitutional doctrine.

This Article examines the purpose and history of the Eighth Amendment Punishments Clause and asserts that juries, rather than judges, should determine whether punishments are unconstitutionally cruel. ${ }^{10}$ Part I provides a brief overview of current Punishments Clause jurisprudence in this country. Part II identifies unconstitutional cruelty as a deeply moral question and explains that Punishments Clause determinations are not the only constitutional moral questions in our justice system that must be resolved. Questions of First Amendment obscenity, for example, are similarly rooted in society's mores. Part III explains that not only are Punishments Clause and obscenity questions

8. See Harris v. Alabama, 513 U.S. 504, 521 (1995) (Stevens, J., dissenting) ("[J]udges are far more likely than juries to impose the death penalty. This has long been the case, and the recent experience of judicial overrides confirms it."). Justice Stevens was appointed to the Supreme Court by President Ford in 1975 and retired in June of 2010.

9. See id. at 521 \& n.8; see also CENTER fOR STUdies IN CRIMINAL Justice, UNIVERSITY of Chicago Law School, Some Data on Juror Attrtudes Towards Capital Punishment 41-46 (stating that juries are more lenient in several types of capital cases, such as when the defendant exhibits "a measure of mental and emotional instability," but also suggesting that judges are more lenient than juries in some capital cases); Michael L. Radelet \& Michael Mello, Death-to-Life Overrides: Saving the Resources of the Florida Supreme Court, 20 FLA. ST. U. L. REV. 195, 196, 213 (1992) (stating that, during the period from 1972 to 1992, Florida judges overrode jury determinations of life imprisonment to impose death sentences in 134 cases-“" 3.6 times" as often as they overrode death sentences to impose sentences of life imprisonment).

10. Although the Eighth Amendment proscribes "cruel and unusual punishments," I have argued elsewhere that the cruelty and unusualness components must be independently assessed and that the cruelty inquiry is akin to the Court's turn to its independent judgment. See Meghan J. Ryan, Does the Eighth Amendment Punishments Clause Prohibit Only Punishments That Are Both Cruel and Unusual?, 87 WASH. U. L. REV. 567, 615-18 (2010); see also infra text accompanying notes $62-66$. 
similar in that they are based on moral values, but also the U.S. Supreme Court's jurisprudence in each of these areas is similar in that the Court directly invokes the evolving nature of law in making both of these constitutional judgments. This Part points out, however, that Punishments Clause and obscenity determinations differ in that judges decide Punishments Clause questions as questions of law whereas juries decide obscenity questions as mixed questions of law and fact. Part III then proceeds to describe the advantage of individualization that jury determinations offer and also addresses some of the concerns that critics ordinarily have about jury decisionmaking, such as legal nonuniformity and the majoritarian difficulty. ${ }^{11}$ Some nonuniformity may be healthy in our constitutional system, though, so that distinct communities have the ability to govern themselves. Moreover, such local sovereignty was central to the impetus behind the drafting and ratification of the Bill of Rights, which embodied concerns about states safeguarding their citizens' rights rather than federally protecting the rights of individuals. These ideals are consistent with the prominent role of the jury-the ultimate body of local self-government with the ability to check the power of the sovereign-in the Bill of Rights. Considering the advantages that juries have to offer and the central role of juries in our constitutional framework, Part IV explores the history of the jury in the United States in an attempt to uncover why First Amendment obscenity issues are considered mixed questions of law and fact for juries to decide while Eighth Amendment Punishments Clause issues are considered legal questions for judges, alone, to resolve. Part IV does not discover any principled reason for this distinction, but it does explain that, while the original power of the jury in the American system waned somewhat in the nineteenth century, the recent cases of Apprendi v. New Jersey ${ }^{12}$ and United States v. Booker ${ }^{13}$ reveal that the jury is again amassing power in the United States. Part V delineates why the reasons for the jury's earlier diminishment are unrelated to any differences between obscenity and Punishments Clause questions. In fact, this Part suggests that if either question is more appropriate for judges to decide, it is the question of obscenity rather than the issue of unconstitutional punishments. Part VI then questions whether procedural difficulties are the reason for the disparate treatment. While juries are more readily

11. Professor Steven Croley stated that "[t]he majoritarian difficulty asks not how unelected/unaccountable judges can be justified in a regime committed to democracy, but rather how elected/accountable judges can be justified in a regime committed to constitutionalism." Steven P. Croley, The Majoritarian Difficulty: Elective Judiciaries and the Rule of Law, $62 \mathrm{U}$. CHI. L. Rev. 689, 694 (1995). This Article uses the term more broadly to refer to the concern that popular rule overwhelms minority rights.

12. 530 U.S. $466(2000)$.

13. 543 U.S. 220 (2005). 
available for decisionmaking in obscenity cases, this Part asserts that any inconvenience associated with involving juries in Punishments Clause adjudications can be remedied with a few modifications to the system and is no reason to ignore the constitutional salience of juries in this context. Instead, juries should be considered essential in resolving these questions, which are rooted in concerns of overreaching central governments and predisposed judges. This Article concludes that juries are well positioned to judge whether imposed, or even proposed, sentences violate the prohibition on cruel and unusual punishments and offers some practical solutions for harnessing juries' acumen in ascertaining society's moral values related to these constitutional questions.

\section{Punishments Clause Background}

The Eighth Amendment Punishments Clause provides that "cruel and unusual punishments" shall not be inflicted. ${ }^{14}$ While the U.S. Supreme Court has interpreted this Clause differently throughout the ages, since 1958 it has consistently held that the prohibition draws "its meaning from the evolving standards of decency that mark the progress of a maturing society." 15 The Court has elaborated on the meaning of the Clause over the past half-century and has erected a brittle framework within which to decide these Punishment Clause cases. ${ }^{16}$ Under the first part of this framework, the Court examines various objective indicia of contemporary values to determine whether a punishment is cruel and unusual. ${ }^{17}$ The primary indicator of these values is legislation adopted by the various U.S. states, the federal government, the District of Columbia, and the U.S. military. ${ }^{18}$ The Court also

14. U.S. CONST. amend. VIII ("Excessive bail shall not be required, nor excessive fines imposed, nor cruel and unusual punishments inflicted.").

15. Trop v. Dulles, 356 U.S. 86, 101 (1958) (plurality opinion).

16. See, e.g., Kennedy v. Louisiana, 554 U.S. 407, 419-20, 443-47 (2008) (suggesting that assessing the evolving standards of decency involves examining the reliability of potential testimony); Atkins v. Virginia, 536 U.S. 304, 311-12, 321 (2002) (consulting the evolving standards of decency in reaching the conclusion that it is unconstitutional to execute mentally retarded individuals).

17. See, e.g., Kennedy, 554 U.S. at 421 ("In these cases the Court has been guided by 'objective indicia of society's standards, as expressed in legislative enactments and state practice with respect to executions." (quoting Roper v. Simmons, 543 U.S. 551, 563 (2005))); Roper, 543 U.S. at 564 (referencing "objective indicia of consensus"); Atkins, 536 U.S. at 312 (referencing "objective evidence of contemporary values" (quoting Penry v. Lynaugh, 492 U.S. 302, 331 (1989) (internal quotation marks omitted)).

18. See Atkins, 536 U.S. at 312 ("We have pinpointed that the "clearest and most reliable objective evidence of contemporary values is the legislation enacted by the country's legislatures."' (quoting Penry, 492 U.S. at 331)). But of. Graham v. Florida, 130 S. Ct. 2011, 2023 (2010) (stating that an examination of state legislative action "is incomplete and unavailing"); Stanford v. Kentucky, 492 U.S. 361, 377 (1989) (suggesting that the actions of 
examines secondary sources that it considers reflective of contemporary values. ${ }^{19}$ These secondary sources include sentencing decisions of juries and judges, ${ }^{20}$ the results of public opinion polls, ${ }^{21}$ the opinions of professional organizations, ${ }^{22}$ the laws of foreign nations, ${ }^{23}$ and international law. ${ }^{24}$ Finally, in the second part of its framework, the Court draws on its own independent judgment to determine whether the objective indicia of contemporary values are consistent with its own views. ${ }^{25}$ Under this rubric, the Court often calls on its understanding of whether the punishment at issue serves the purposes of retribution and deterrence. $^{26}$

In some cases-most typically when the case does not involve the death penalty-the Court varies its two-part framework somewhat in

juries are equally important). While the Court has been rather consistent in consulting legislative action, it has been somewhat inconsistent in its analysis of this data. Compare Kennedy, 554 U.S. at 422-26 (determining that imposing the death penalty for the crime of child rape was unconstitutional by focusing on the fact that only six states imposed the punishment), with Atkins, 536 U.S. at 315-16 (focusing on the "consistency of the direction of change" in the number of states permitting the punishment).

19. See Ryan, supra note 10, at 588-89.

20. See, e.g., Graham, 130 S. Ct. at 2023 ("Actual sentencing practices are an important part of the Court's inquiry into consensus."); Gregg v. Georgia, 428 U.S. 153, 181 (1976) ("The jury also is a significant and reliable objective index of contemporary values because it is so directly involved." (citing Furman v. Georgia, 408 U.S. 238, $439-40$ (1972) (Powell, J., dissenting))).

21. See, e.g., Penry, 492 U.S. at 334-35 (examining evidence from public opinion polls).

22. See, e.g., Atkins, 536 U.S. at 316 n.21 (noting that the opinions of professional organizations confirm that the legislative judgment reflects a broader professional consensus).

23. See, e.g., Graham, $130 \mathrm{~S}$. Ct. at 2033 ("There is support for our conclusion in the fact that, in continuing to impose life without parole sentences on juveniles who did not commit homicide, the United States adheres to a sentencing practice rejected the world over."); Roper v. Simmons, 543 U.S. 551, 575-76 (2005) (examining the laws of other nations).

24. See, e.g., Roper, 543 U.S. at 575-78 (examining international opinion); Atkins, 536 U.S. at $316 \mathrm{n} .21$ (noting that evidence, including that of international opinion, "makes it clear that this legislative judgment reflects a much broader social ... consensus"). Whether the Court's consultation of the actions and opinions of other nations, as well as international law, is appropriate remains a topic of debate.

25. The actual significance of the Court's reliance on its own independent judgment remains questionable. The Court claims that its own judgment is a factor in determining whether a punishment is unconstitutionally cruel and unusual, yet the Court has never found its own judgment to compel a conclusion different from one it reached based on the objective indicia of contemporary values. See Roper, 543 U.S. at 615-16 (Scalia, J., dissenting) (stating that the Court's resort to its independent judgment is a "rule ... reflected solely in dicta and never once in a holding that purports to supplant the consensus of the American people with the Justices' views ...."); William C. Heffernan, Constitutional Historicism: An Examination of the Eighth Amendment Evolving Standards of Decency Test, 54 AM. U. L. REv. 1355, 1380-81 (2005) (arguing that "there is no case in which the majority's 'independent judgment' has diverged from their conclusions about contemporary standards of decency," thus "[t]he public-sentiment dog has wagged the tail of independent judicial judgment").

26. See Meghan J. Ryan, Judging Cruelty, 44 U.C. DAVIS L. REv. 81, 101 (2010). 
determining the constitutionality of a punishment. In Solem v. Helm, ${ }^{27}$ for example, the Court assessed the constitutionality of a punishment of life without the possibility of parole by examining whether the gravity of the offense was grossly disproportionate to the harshness of the penalty, whether other similarly situated defendants within the same jurisdiction had received similar punishments, and whether other jurisdictions imposed commensurate punishments for similar crimes. ${ }^{28}$ The Court referred to these factors as "objective" in nature, ${ }^{29}$ and indeed the latter two factors are similar to the Court's consultation of state legislative action and actual punishments imposed under its "objective indicia of contemporary values" inquiry in its traditional Punishments Clause analysis. ${ }^{30}$ Just as the Court tallies the number of jurisdictions that have adopted or prohibited a particular punishment, and examines the punishments juries have imposed, under its traditional analysis, the Solem Court assessed the jurisdictions that imposed similar punishments for similar crimes. ${ }^{31}$ Under this alternative approach to the Punishments Clause, though, the Court did not explicitly turn to its own independent judgment, as it traditionally does. ${ }^{32}$ Yet, its assessment of whether the gravity of the offense was grossly disproportionate to the harshness of the penalty was a matter of the Court's subjective judgment. ${ }^{33}$ While "there are widely shared views as to the relative seriousness of crimes"

27. 463 U.S. 277 (1983).

28. See id. at 290-92 ("[A] court's proportionality analysis under the Eighth Amendment should be guided by objective criteria, including (i) the gravity of the offense and the harshness of the penalty; (ii) the sentences imposed on other criminals in the same jurisdiction; and (iii) the sentences imposed for commission of the same crime in other jurisdictions."); id. at 296-300 (applying these factors). Whether the Solem Court's approach is still binding law is somewhat unclear after the Court's fragmented holdings in later noncapital Eighth Amendment cases. See Norris v. Morgan, 622 F.3d 1276, 1286 (9th Cir. 2010) (stating that the Supreme Court's jurisprudence in this area is in "disarray"); Hawkins v. Hargett, 200 F.3d 1279, 1281 (10th Cir. 1999) (stating that the Court's Harmelin v. Michigan, 501 U.S. 957 (1991), "left the meaning of Solem less than clear"). Compare, e.g., United States v. Nigg, 667 F.3d 929, 938 (7th Cir. 2012) (referencing the Solem three-factor test); United states v. Gurule, 461 F.3d 1238, 1247 (10th Cir. 2006) (stating that the Solem Court "established a three-pronged analysis for reviewing Eighth Amendment proportionality challenges, but subsequently ... the Court substantially narrowed that approach and instructed that courts should not go beyond the first prong in most cases"); United States v. MacEwan, 445 F.3d 237, 247-50 (3d Cir. 2006) (applying Solem), with Norris, 622 F.3d at 1286 (stating that the Solem "approach was short-lived"); Hawkins, 20 F.3d at 1282 $\&$ n. 1 (explaining that the Solem proportionality test was narrowed in Harmelin as discussed by Justice Kennedy's concurrence in Harmelin).

29. Id. at 292 .

30. See supra text accompanying notes 17-18.

31. But see supra note 28 (explaining that the three-factor proportionality test may have been narrowed after Solem).

32. See supra text accompanying notes $25-26$.

33. See id. 
as the Solem Court contended, ${ }^{34}$ there is little agreement as to actual or weighted seriousness of these offenses. ${ }^{35}$ Accordingly, the Court must engage in some line-drawing under this analysis. ${ }^{36}$ Ultimately, this question of gross disproportionality is similar to the Court's turn to its independent judgment under its traditional Punishments Clause analysis. $^{37}$ They both reduce to a question of whether imposing this sentence on this offender is, in the Court's judgment, unacceptably cruel. $^{38}$

In contrast to this case-by-case approach ${ }^{39}$ of gross disproportionality that the Court has employed in noncapital cases, the Court's traditional Punishments Clause analysis used in capital cases is often categorical in nature. For example, in Atkins $v$. Virginia, ${ }^{40}$ the Court concluded that it is unconstitutional to execute any individual who is "mentally retarded," not that it was unconstitutional to execute the offender Daryl Renard Atkins due to his own incapacities. 42

34. Solem, 463 U.S. at 292.

35. See Paul H. Robinson \& Robert Kurzban, Concordance and Conflict in Intuitions of Justice, 91 MINN. L. REV. 1829, 1832-37 (2007) (underscoring the difficulty in determining cardinal ranking of punishments); see also Meghan J. Ryan, Proximate Retribution, 49 Hous. L. REV. 1047, 1062 (forthcoming 2012) (explaining that there is little agreement as to the cardinal ranking of offenses).

36. See Solem, 463 U.S. at 295 (explaining that "[i]t is clear that a 25 -year sentence generally is more severe than a 15-year sentence, but in most cases it would be difficult to decide that the former violates the Eighth Amendment while the latter does not").

37. Although it is unclear whether the Solem Court's three-step approach to Punishments Clause constitutionality is still controlling, see supra note 28 , the question of gross disproportionality, which mirrors the Court's traditional turn to its own judgment, remains good law. See Ewing v. California, 538 U.S. 11, 20 (2003) ("The Eighth Amendment . . . contains a 'narrow proportionality principle' that 'applies to noncapital sentences."').

38. Cf. Ryan, supra note 26 (explaining that the cruelty inquiry is related to the Court's current resort to its own independent judgment in Punishments Clause analysis).

39. $C f$. id. (comparing the Court's Punishments Clause gross disproportionality analysis to Sixth Amendment speedy trial determinations, which are determined on a case-by-case basis).

40. 536 U.S. 304 (2002).

41. While "mentally retarded" may be viewed as an offensive term, it is the term that the Supreme Court has employed in this context. See id. passim; Ryan, supra note 26, at 93 n.59.

42. Atkins, 536 U.S. at 321 (concluding that "the execution of mentally retarded criminals ... is excessive and that the Constitution 'places a substantive restriction on the State's power to take the life' of a mentally retarded offender" (quoting Ford v. Wainwright, 477 U.S. 399, 405 (1986))). Interestingly, the Court's categorical approach in this, and other Punishments Clause cases, is arguably contrary to the principle of judicial minimalism. $C f$. Rescue Army v. Municipal Court, 331 U.S. 549, 568-69 (1947) (describing the Court's "policy of strict necessity in disposing of constitutional cases," which includes its rule not to determine constitutional matters "in broader terms than are required by the precise facts to which the ruling is to be applied"); CASS R. Sunstein, ONE CASE AT a timE: Judicial Minimalism ON THE SUPREME COURT xi (1999) ("The current Supreme Court embraces minimalism. Indeed, judicial minimalism has been the most striking feature of American law in the 1990s."). 
Similarly, in Roper $v$. Simmons, ${ }^{43}$ the Court concluded that it is unconstitutional to execute any individual who was a juvenile when he committed the crime at issue, not that it was unconstitutional to execute the offender Christopher Simmons in the case at hand for committing first-degree murder. ${ }^{44}$ In contrast, in noncapital cases, the Court has often taken a more fact-specific approach in its Punishments Clause determinations. For example, in the Solem case, the Court determined that the punishment of life imprisonment without the possibility of parole was unconstitutionally cruel and unusual for the crime of uttering a "no account check" even though the defendant was a habitual offender under state law, having previously been convicted three times of thirddegree burglary and also having been convicted of obtaining money under false pretenses, grand larceny, and "third-offense driving while intoxicated." ${ }^{45}$ The Solem Court did not create a categorical rule, as it did in Atkins and Roper, by, for example, concluding that heightened sentences for habitual offenders in general are unconstitutional or even that seventh-time nonviolent felons cannot constitutionally be sentenced to life in prison without the possibility of parole.

Although the Court has historically based its varying Punishments Clause analyses on this distinction between capital and noncapital cases, the Court recently upset this distinction in Graham v. Florida. ${ }^{46}$ In that case, the Court adopted a categorical approach-and its concomitant reliance on objective indicia of contemporary values and the Court's own independent judgment - to determine the constitutionality of the punishment of life imprisonment without the possibility of parole for a crime that did not involve homicide. ${ }^{47}$ The Court's unexpected adoption of the categorical approach in a noncapital case suggests that the Court may be moving toward a more categorical jurisprudence in this area. Accordingly, it seems that the Court may focus less on the specific facts of a case and more on broad classifications of the crimes and offenders at issue.

While the Court seems to be increasingly conforming to its traditional reliance on the objective indicia of contemporary values and the Court's own independent judgment, scholars have criticized this two-part analysis that the Court employs as disingenuous. ${ }^{48}$

43. 543 U.S. 551 (2005).

44. See id. at 578-79.

45. Solem, 463 U.S. at 279-81, 303 (internal quotation marks omitted). "A third offense of driving while under the influence of alcohol [was] a felony" under state law. Id. at 280 n.4.

46. 130 S. Ct. $2011(2010)$.

47. See id. at 2017-18, 2022-23.

48. See, e.g., Tonja Jacobi, The Subtle Unraveling of Federalism: The Illogic of Using State Legislation as Evidence of an Evolving National Consensus, 84 N.C. L. REV. 1089, 1091 (2006) ("Although justified in terms of deference to state legislatures, the reliance on state legislation to prove a national consensus regarding the application of the Eighth Amendment 
Formalistically, the Court's reliance on its two-part "evolving standards of decency" test seems to depend primarily on the notion of unusualness in proscribing particular punishments under the Eighth Amendment. ${ }^{49}$ This derives from the Court's systematic method of tallying the number of jurisdictions that have adopted or rejected a particular practice. ${ }^{50}$ Yet scholars have accused the Court of, in practice, relying solely, or at least primarily, on its independent judgment in determining the constitutionality of punishments. "They have said that this "shifts from the people to the judiciary the powers to define the empirical limits of personal liberty and equality" and is thus undemocratic. ${ }^{52}$ Instead of citizens determining what punishments are appropriate, the Court, a "small and unrepresentative segment of our society," reserves this power for itself. ${ }^{53}$ Further, scholars have described the Court's turn to its own judgment as "suspect in terms of its sociological legitimacy, which depends on the public perception that the Court is adhering to principled legal norms." ${ }^{, 54}$ The perception that the Court does not adhere to principled legal norms likely stems from its inconsistency in how it reaches its independent-judgment determinations. In addition to the theories of retribution and deterrence, ${ }^{55}$ the Court has relied on a potpourri of other factors-such as the principle that the punishment of

does violence to constitutional federalism and imposes judicial preferences under the facade of judicial modesty."); Mary Sigler, The Political Morality of the Eighth Amendment, 8 OHг ST. J. CRIM. L. 403, 415 (2011) (suggesting that the Court may be "clinging to majoritarian considerations" in order to "mask" its "reliance on its own subjective judgment"); John F. Stinneford, Evolving Away from Evolving Standards of Decency, 23 FED. SENT'G REP. 87, 89 (2010) ("Going forward, the Supreme Court appears set to rely primarily on its own judgment in all cases arising under the Cruel and Unusual Punishments Clause and to use the evolving standards of decency test as little more than a prop."); see also, e.g., John F. Stinneford, Rethinking Proportionality Under the Cruel and Unusual Punishments Clause, 97 VA. L. REv. 899, 920-23 (2011) (asserting that the Court's reliance on its own independent judgment "has ... led to a jurisprudence that is standardless and disingenuous").

49. See Ryan, supra note 10 , at 593 ("Regardless of whether the Court understands cruelty and unusualness to be distinct concepts, the Court's application of its 'evolving standards of decency' test appears to base its Punishments Clause inquiries primarily on the ground of unusualness.").

50. See id.; supra text accompanying note 18.

51. See supra note 48.

52. Evelyn Keyes, Two Conceptions of Judicial Integrity: Traditional and Perfectionist Approaches to Issues of Morality and Social Justice, 22 NOTRE DAME J.L. ETHICS \& PUB. POL'Y 233, 286-91 (2008); see also supra note 48 (noting criticisms of the Court's analysis).

53. Thompson v. Oklahoma, 487 U.S. 815, 873 (1988) (Scalia, J., dissenting); see also Roger P. Alford, Roper v. Simmons and Our Constitution in International Equipoise, 53 UCLA L. REv. 1, 17 (2005) (stating that the Court's reliance on its own judgment risks "judicial hegemony and substantive indeterminacy").

54. Alford, supra note 53 , at 17.

55. See supra text accompanying note 26 . 
death is worse than other punishments available under the law, ${ }^{56}$ defendants' competencies, ${ }^{57}$ the threat of wrongful execution, ${ }^{58}$ and even the reliability of certain pieces of evidence presented in the trial court $^{59}$-in forming its judgment under this prong of the analysis. ${ }^{60}$ This inconsistency has led scholars to throw up their hands in exasperation and has created an unpredictable Eighth Amendment jurisprudence. ${ }^{61}$

Regardless, the Court's independent judgment is central to determinations of whether punishments are unconstitutionally cruel and unusual. I have argued elsewhere that the text of the Punishments Clause, as well as the Court's earliest cases, suggest that punishments must be both cruel and unusual to be prohibited under the Clause. ${ }^{62}$ Thus, the cruelty and unusualness components of the Clause must be independently assessed to give full meaning to the prohibition. ${ }^{63}$ The Court's current practice of examining state sentencing practices addresses the unusualness aspect of the prohibition, but independently assessing the concept of cruelty is more difficult. ${ }^{64}$ Perhaps the Court could do this by focusing its independent judgment more carefully on the concept of cruelty and analyzing specific identified factors targeted

56. See Ryan, supra note 26 , at $99-100$.

57. See id. at $99,117-18$.

58. See, e.g., Kennedy v. Louisiana, 554 U.S. 407, 443 (2008) (expressing the Court's concern about the "special risk of wrongful execution' in some child rape cases" (quoting Atkins v. Virginia, 536 U.S. 304, 321 (2002))); Atkins, 536 U.S. at 321 (stating that "[m]entally retarded defendants in the aggregate face a special risk of wrongful execution").

59. See Kennedy, 554 U.S. at 443 (expressing concern about "[ $t$ ]he problem of unreliable, induced, and even imagined child testimony" in capital cases).

60. See Ryan, supra note 26 , at $99-119$ (discussing a variety of factors upon which the Court relies).

61. See, e.g., John D. Castiglione, Qualitative and Quantitative Proportionality: A Specific Critique of Retributivism, 71 OHo ST. L.J. 71, 75 (2010) (stating that "[i]t has become conventional wisdom that Eighth Amendment proportionality jurisprudence is a mess"); Tom Stacy, Cleaning Up the Eighth Amendment Mess, 14 WM. \& MARY BILl RTs. J. 475, 476 (2005) ("The Court's jurisprudence under the Eighth Amendment's Cruel and Unusual Punishment Clause stands in disarray."). These methodological difficulties are exacerbated by the Court's inconsistency in its basic interpretation of the Punishments Clause. Frequently, the Court interprets the prohibition on "cruel and unusual punishments" as a term of art, the meaning of which is determined by the Court's reliance on the two-part "evolving standards of decency" test. Occasionally, however, the Court has interpreted the Clause to more closely track the text of the Eighth Amendment and has specified that a punishment must be both cruel and unusual to be constitutionally prohibited. See Ryan, supra note 10, at 592-93; e.g., Harmelin v. Michigan, 501 U.S. 957, 994 (1991) (rejecting an allegation of cruel and unusual punishment because, while the punishment at issue "may [have been] cruel, [it was] not unusual in the constitutional sense"). This latter interpretation is not only more consistent with the text of the Punishments Clause, but it is also more consistent with how the language of the Clause was originally interpreted. See Ryan, supra note 10, at 604-15.

62. See Ryan, supra note 10 , at 605.

63. See id. at $601-04,615$.

64. See id. at 615-17; Ryan, supra note 26 , at 120-21. 
at this idea. ${ }^{65}$ While more carefully focusing the Court's independentjudgment analysis would be a relatively simple solution to impose, it fails to solve the problem that judges tend not to be representative of American society. ${ }^{66}$ While nearly $51 \%$ of Americans are female, for example, only three of the nine current U.S. Supreme Court Justices, or $33 \%$, are female, and only about $22 \%$ of the federal judiciary overall is female. ${ }^{67}$ Moreover, while $44 \%$ of the Justices are of age sixty-five or older, only $12.9 \%$ of Americans are sixty-five or older. ${ }^{68}$ And of course the vast majority of judges are highly educated, having obtained juris doctors, whereas less than a third of U.S. citizens have completed college degrees. ${ }^{69}$ If judges are not representative of society, one must ask whether they have other qualifications that make them competent to define the contours of cruelty.

\section{QUESTIONS OF MORALITY}

Determining whether a punishment is cruel is in most estimations a question of morality. ${ }^{70}$ Professor Michael Moore has explained that

65. See generally Ryan, supra note 26 (arguing that the Court should rein in its independent-judgment analysis in the Punishments Clause context).

66. See supra text accompanying note 53 .

67. Compare U.S. Census Bureau, Population Division, Table 7. Resident Population by Sex and Age: 1980 to 2009, http:/www.census.gov/compendia/statab/2011/tables/11s0007.pdf (last visited Feb. 5, 2012), with Biographies of Current Justices of the Supreme Court, http://www.supremecourt.gov/about/biographies.aspx (last visited Feb. 5, 2012) and Federal Judiciary Center, Biographical Directory of Judges, Fed. Judiciary Center, at www.fjc.gov/hisory/home.nsf/page/judges.html (last visited Mar. 11, 2012). Further, while about $16 \%$ of Americans are Hispanic, only about $6 \%$ of federal judges are Hispanic, and while nearly $5 \%$ of Americans are of Asian descent, only about $1 \%$ of federal judges are Asian American. Compare Overview of Race and Hispanic Origin: 2010, available at www.census.gov/ prod/cen2010/briefs/c2010br-02.pdf (last visited Mar. 11, 2012), with Federal Judiciary Center, supra. The information on the federal judiciary was obtained by visiting the Federal Judiciary Center's section on "Federal Judicial History": "Judges of the United States Courts" and selecting research categories on "Gender" and "Race or Ethnicity" and limiting the queries to sitting judges. Cf. Pat K. Chew \& Luke T. Kelley-Chew, The Missing Minority Judges, 14 J. GENDER RACE \& JUST. 179, 196 n.197 (employing similar searches by employing the Federal Judiciary Center's resources).

68. Meaningful computations of the average age of federal judges is more complicated because senior judges, who tend to be older, often handle fewer cases than active judges, creating less of an impact.

69. See Educational Attainment by Race and Hispanic Origin: 1970 to 2010, available at http://www.census.gov/compendia/statab/2012/tables/12s0229.pdf.

70. See Laurence Claus, Methodology, Proportionality, Equality: Which Moral Question Does the Eighth Amendment Pose?, 31 HARV. J.L. \& PUB. PoL'Y 35, 38 (2008) (noting that cruelty, while somewhat ambiguous in meaning, "invites a moral inquiry"). See generally Ronald J. Allen, Moral Choices, Moral Truth, and the Eighth Amendment, 31 HARV. J.L. \& PUB. POL'Y 25, 30-31 (2008) (noting that "evolving standards" in the Eighth Amendment context can be derived from subjective moral beliefs); Michael S. Moore, Morality in Eighth Amendment Jurisprudence, 31 HARV. J.L. \& PUB. POL'Y 47 (2008) (examining the role of morality in Eighth 
there are various possible sources for morality-based judgments under the Eighth Amendment. ${ }^{71}$ Judges may engage in first-person judgments by relying on their own personal values; ${ }^{72}$ they may rely on third-person judgments, basing their decisions on what other groups of individuals believe is morally correct; ${ }^{73}$ or they may draw on both of these sources, as the Court has traditionally done in its Punishments Clause jurisprudence, by avowedly relying both on "objective indicia of contemporary values" and its own independent judgment. ${ }^{74}$ Professor Ronald Allen has argued, however, that there is no "truth value" to be found in moral propositions and that judges have no greater insight into moral values than anyone else does. ${ }^{75}$ This suggests that judges' firstperson moralizing should be patrolled by society. ${ }^{76}$ But there are also difficulties with judges engaging in third-person moralizing. Groups and individuals often differ in their determinations of what is moral or immoral, and how is a judge to decide which group or individual is correct? $^{77}$

That an issue of morality is at the core of a constitutional question, as in the Punishments Clause context, is not unique; questions of morality are implicit in other constitutional inquiries as well. Under the constitutional requirements of substantive due process, for example, moral values creep into questions such as whether abortion is a constitutional right ${ }^{78}$ and whether sexual relations between individuals

Amendment jurisprudence). I have argued elsewhere, however, that the concept of cruelty as enshrined in the Punishments Clause is actually more complicated, instead reflecting notions of exceptional brutality and inflicting pain for a purpose other than punishment. See Ryan, supra note 26 , at 121-40. Identifying these factors might fall outside of the traditional boundaries of moral reasoning, but they are still issues that juries are well situated to determine, as they are heavily rooted in facts rather than purely in law.

71. See Moore, supra note 70 , at 53-58.

72. Some commentators refer to this as "critical morality," but Professor Moore prefers to refer to it as "committed, first-person judgments about morality." Id. at 53.

73. Professor Moore refers to this as "moral sociology." $1 d$. at 53.

74. See id. at 53 ("Justice Stewart's opinion in Gregg and Justice Kennedy's opinion in Roper clearly distinguish these [first-person and third-person] sources of moral values, and in fact use both first-person and third-person judgments quite explicitly. They have tried to make Eighth Amendment jurisprudence a mixture of both kinds of moral reasoning.").

75. See Allen, supra note 70 , at 28,31 .

76. See id. at 34 (explaining the need for citizens to patrol the judiciary).

77. Cf. Moore, supra note 70, at 55-58 (examining some of the varying populations that a judge could consult when engaging in third-person moralizing). Professor Moore explains that judges could base their third-person moralizing on opinions held by "everyone in the world," "only English-speaking peoples," "citizens of the United States," or even a "subset of the United States," such as our "ethical leaders." Id. at 56-57.

78. See Planned Parenthood of Se. Pa. v. Casey, 505 U.S. 833, 893-95 (1992) (holding that the spousal notification provision of Pennsylvania's abortion statute was unconstitutional on the ground that it imposed an "undue burden" on a woman's ability to procure an abortion, and determining that other portions of the statute did not impose such an unconstitutional "undue 
of the same sex may constitutionally be criminalized. ${ }^{79}$ In determining whether there has been a violation of one's substantive due process right, the Court has asked whether there is "a deeply embedded moral consensus" supporting that right. ${ }^{80}$ And scholars have debated whether judges should engage in moral reasoning, or consult the principles of natural law, in determining what is protected under substantive due process guarantees. ${ }^{81}$ However, in contrast to the debate on the question of morality in the Eighth Amendment context, the discussion in the substantive due process arena focuses more on whether judges should engage in moral reasoning at all, rather than on how they should engage in it. 82

burden"); Roe v. Wade, 410 U.S. 113, 164 (1973) (holding that "[a] state criminal abortion statute ... that excepts from criminality only a life-saving procedure on behalf of the mother, without regard to pregnancy stage and without recognition of the other interests involved, is violative of the Due Process Clause of the Fourteenth Amendment").

79. See Lawrence v. Texas, 539 U.S. 558, 578 (2003) (overruling Bowers v. Hardwick, 478 U.S. 186 (1986), and striking down Texas's statute criminalizing homosexual conduct). For further details on the story surrounding Lawrence v. Texas, see DALE A. CARPENTER, FLAGRANT CONDUCT: THE STORY OF LAWRENCE V. TEXAS (forthcoming Mar. 2012).

80. ERWIN ChemerINSKY, CONSTITUTIONAL LAW 947 (3d ed. 2009) (noting that some "scholars maintain that the Court should recognize non-textual fundamental rights that are supported by a deeply embedded moral consensus that exists in society" (citing Harry H. Wellington, Common Law Rules and Constitutional Double Standards: Some Notes on Adjudication, 83 YALE L.J. 221, 284 (1973))); see also Ryan, supra note 10, at 619-20 (exploring morality in the substantive due process context); e.g., Lawrence, 539 U.S. at 568-75 (examining the growing moral consensus that homosexual conduct should not be punished in addition to exploring the nation's history of enacting laws "directed at homosexual conduct").

This question of moral values, however, is not the only question that the Court asks when determining whether there has been a violation of substantive due process. In addition to this question, it sometimes asks whether a right is "deeply rooted in this Nation's history and tradition." See, e.g., Moore v. City of East Cleveland, 431 U.S. 494, 503 (1977); see also Ryan, supra note 10, at 619 (explaining the Court's reliance on history and morality in the substantive due process context). The Court's jurisprudence in this area is quite convoluted, and it is difficult to determine one distinctive test that the Court employs here. See Daniel O. Conkle, Three Theories of Substantive Due Process, 85 N.C. L. REV. 63, 121 (2006) (explaining the Court's various approaches in the substantive due process context and suggesting that Lawrence introduced a "distinctive theory of substantive due process, a theory of evolving national values").

81. See Mattei Ion Radu, Incompatible Theories: Natural Law and Substantive Due Process, 54 VILL. L. REv. 247, 279-84 (2009) (referencing scholars who have taken differing positions on the role that natural law should play in substantive due process decisionmaking).

82. See Carlos A. Ball, Why Liberty Judicial Review is as Legitimate as Equality Review: The Case of Gay Rights Jurisprudence, 14 U. PA. J. CONST. L. 1, 16 (2011) ("One of the frequent criticisms of substantive due process doctrine is that it encourages (or allows) judges to incorporate into the constitutional analysis their personal views about the moral and policy positions behind the legislation that is subject to challenge."); Cass R. Sunstein, Due Process Traditionalism, 106 MiCH. L. REV. 1543, 1545 (2008):

[T] he major fault line within the Court has long been between those who seek 
Morality is also at the heart of judgments on whether certain speech is obscene and therefore completely unprotected by the First Amendment. ${ }^{83}$ Although the First Amendment provides that "Congress shall make no law... abridging the freedom of speech, or of the press," $" 84$ the Court has determined that obscenity is not protected by the First Amendment under any circumstances. ${ }^{85}$ What constitutes obscenity is not entirely clear though. Justice Potter Stewart famously stated in 1964 that he simply "know[s] it when [he] see[s] it." Providing a bit more guidance, the Court in Miller v. California ${ }^{87}$ concluded that speech is obscene when (a) "the average person, applying contemporary community standards' would find that the work, taken as a whole, appeals to the prurient interest"; (b) "the work depicts or describes, in a patently offensive way, sexual conduct specifically defined by the applicable state law"; and (c) "the work, taken as a whole, lacks serious literary, artistic, political, or scientific value." Just like the question of cruelty in the Eighth Amendment context and the question of "a deeply embedded moral consensus" under substantive due process, each prong of the Miller test reduces to a question of individuals' moral judgments. The first prong probes the community's own current standards regarding the morality of the speech under review, ${ }^{89}$ and the second prong, which deals with moral subject of "patent[] offensive[ness]," has been clarified to similarly invoke contemporary community standards. ${ }^{90}$ The third prong of the Miller test, while also drawing on a community's mores, examines the values of a somewhat different community. Where the first and second prongs turn to the local community for moral values, the third prong adopts a broader, arguably national, community. ${ }^{91}$ Although this community

to limit the reach of the Due Process Clause to rights that long-standing traditions recognize as such, and those who believe either that evolving traditions are what matter or that the Court legitimately brings its own moral judgments to bear on substantive due process questions.

83. See U.S. CONST. amend. I.

84. Id.

85. Roth v. United States, 354 U.S. 476, 484 (1957).

86. Jacobellis v. Ohio, 378 U.S. 184, 197 (1964) (Stewart, J., concurring) ("I shall not today attempt further to define the kinds of material I understand to be [obscene]; and perhaps I could never succeed in intelligibly doing so. But I know it when I see it ....").

87. 413 U.S. 15 (1973).

88. Id. at 24 (quoting Kois v. Wisconsin, 408 U.S. 229, 230 (1972)).

89. See id. at 24.

90. Id. at 30; see also Smith v. United States, 431 U.S. 291, 300-01 (1977) (explaining that Miller makes clear that both the prurient interest and the patent offensiveness prongs are to be determined based on "contemporary community standards").

91. See Pope v. Illinois, 481 U.S. 497, 500-01 (1987); see also Smith, 431 U.S. at 301 ("Literary, artistic, political, or scientific value... is not discussed in Miller in terms of 
varies in form from the communities under the first two prongs, this serious-value component of the Miller test is still based on society's moral standards.

\section{Similar CONTEXTS, VARYING APPROACHES}

Not only are the Court's First Amendment obscenity analysis and its Eighth Amendment Punishments Clause analysis similar in that they involve delving into questions of morality, but they both also explicitly examine evolving societal norms in a way that the Court's substantive due process analysis does not. ${ }^{92}$ Certainly, there has been debate for centuries over whether constitutional interpretation should yield to

contemporary community standards."); cf. Obscenity, 87 HARV. L. REV. 160, 169 (1973) ("Some measure of close appellate supervision may be retained after Miller since it appears that only prurient appeal and patent offensiveness will be determined under state standards, while 'serious value' apparently will be measured by national standards."). The Court has stated that this broader community's values are to be determined by the standard of an objective reasonable person. See Pope, 481 U.S. at 500-01; Scot A. Duvall, A Call for Obscenity Law Reform, 1 WM. \& MARY BILL RTS. J. 75, 83-84 (1992). As the Miller Court explained, "[t]he First Amendment protects works which, taken as a whole, have serious ... value, regardless of whether the government or a majority of the people approve of the ideas these works represent." 413 U.S. at 34. Therefore, "the value of the work [should not] vary from community to community based on the degree of local acceptance it has won." Pope, 481 U.S. at 500. Instead, the Court determined that the relevant standard to be applied in determining the serious value of a work is "whether a reasonable person would find such value in the material, taken as a whole." Id. at 501. Commentators have concluded that this means an objective, national standard should be applied when determining the serious value of a work. See, e.g., Jack E. Brown, New Law for the Internet, 28 ARIZ. ST. L.J. 1243, 1250 n.53 (1996) ("The third element (frequently referred to as the 'redeeming social value' test) has been declared to be an objective test based on national standards."); David Cole, Playing by Pornography's Rules: The Regulation of Sexual Expression, 143 U. PA. L. REv. 111,112 n.6 (1994) ("In Pope v. Illinois, ... the Court held that in judging whether a work has 'serious literary, artistic, political, or scientific value,' the Court must apply a national 'reasonable person' standard."); Duvall, supra, at 87 ("[F]or the serious value prong, the Supreme Court assumed a generic, arguably national, community of 'reasonable persons' who have objective standards.... As a matter of constitutional law, the contemporary community standard for the value of a specific work must be the same throughout the United States."). Whether the work has serious value, as determined by the objective standard of the national community's mores, is to be decided by a local jury. See Miller, 413 U.S. at 26 \& $n .9$ (explaining that "we must continue to rely on the jury system" and noting that "[t] $]$ he mere fact juries may reach different conclusions as to the same material does not mean that constitutional rights are abridged"); see also Edward John Main, The Neglected Prong of the Miller Test for Obscenity: Serious Literary, Artistic, Political, or Scientific Value, 11 S. ILL. U. L.J. 1159, 1161 (1987) (stating that Miller "suggest[s] that the determination of the value of a work should be left to the jury .....'); PATTERN CRIMINAL JURY INSTRUCTIONS FOR THE DISTRICT COURTS OF THE FIRST CIRCUIT 141 (2008), available at http://federalcriminaljuryinstructions .com/uploads/1st_Circuit_Criminal_Instructions_2008_Revision.pdf (including in the model instructions for an offense involving obscenity the elements of the Miller test).

92. While the First and Eighth Amendment analyses focus on evolving or contemporary standards, the substantive due process analysis focuses on the past by examining our nation's traditions. 
changing societal norms. ${ }^{93}$ Simply put, most constitutional interpreters are considered either originalists or living constitutionalists (or nonoriginalists) in some form. ${ }^{94}$ Originalists tend to privilege history in their interpretations of the Constitution, whereas living constitutionalists do not privilege history and tend to favor interpretations of the document that evolve with changing society. ${ }^{95}$ Some Supreme Court Justices have endorsed particular methods of constitutional interpretation. Justice Antonin Scalia, for example, is well known for his "faint-hearted" originalism. ${ }^{96}$ However, the Supreme Court as a whole has not endorsed any overall method of constitutional interpretation. ${ }^{97}$ Instead, many of its cases vary in the constitutional

93. See Lackland H. Bloom., JR., Methods of Interpretation: How the Supreme COURT READS THE CONSTITUTION xx (2009) (explaining that various methods of constitutional interpretation have been used "throughout our constitutional history").

94. See Jack M. Balkin, Abortion and Original Meaning, 24 Const. CoMmENT. 291, 29293 (2007) (describing the debate between originalists and living constitutionalists and asserting that the choice between the two camps is a false one); Marc $O$. DeGirolami, The Vanity of Dogmatizing, 27 CONST. COMMENT. 201, 217 (2010) ("The major competitor to originalism of whatever variety has generally gone under the name of 'nonoriginalism' or 'living constitutionalism.'"). See generally Antonin Scalia, Originalism: The Lesser Evil, 57 U. CIN. L. REV. 849 (1989) (setting forth the dichotomy between originalism and nonoriginalism). Of course asserting that originalism and living constitutionalism, or nonoriginalism, are the two (major) methods of constitutional interpretation is greatly oversimplifying the matter. Scores of books and articles have been devoted to chasing down various species and nuances of constitutional interpretation, and this Article will not even attempt to summarize the vast scholarly literature on the subject. For a good taxonomy of major methods of constitutional interpretation, however, see PHILIP BOBBITT, Constitutional Fate: TheORY OF THE CONSTITUTION (1982).

95. See David A. Strauss, The Living Constitution 1 (2010) ("A 'living constitution' is one that evolves, changes over time, and adapts to new circumstances, without being formally amended."); DeGirolami, supra note 94, at 217-18 (distinguishing living constitutionalists from originalists).

96. Scalia, supra note 94 , at 864 ("I hasten to confess that in a crunch I may prove a fainthearted originalist.").

97. See BLOOM, supra note 93, at xviii-xix ("More often than not, the Court relies on a variety of interpretive techniques in reaching its decision."). Professor Lackland Bloom has explained that:

It is rare ... for the Court to rely on only one methodology in deciding a major case. All of these methods of interpretation have long been and continue to be influential because they can be quite persuasive. In explaining why a case has been decided in a particular manner, in criticizing a decision in a dissenting opinion, or in defending an opinion against such criticism, a justice will almost certainly use every weapon available. Thus, it is not uncommon for an opinion to rely on a variety of different interpretive methods, to the point where it is difficult-if not impossible - to attribute the result to any particular approach.

Id. at 419. 
methods used-even within the same areas of law. ${ }^{98}$ In most instances, the Court ties itself to its legal doctrines and precedents, and many of these are not specifically rooted in any particular method of constitutional interpretation. ${ }^{99}$ The Court's frameworks for analysis in the areas of First Amendment obscenity and Eighth Amendment Punishments Clause law, though, are atypical in that they are more securely tethered to a particular method of constitutional interpretation. By focusing on "community standards" in the obscenity context, and "evolving standards" in the Eighth Amendment context, ${ }^{100}$ the Court's primary standards for constitutionality in these contexts seem to be tied to a notion of living constitutionalism rather than rooted in history as many originalists would prefer. This is apart from whether following a living-constitutional approach is best in these contexts. And the community and evolving standards of the Court's First and Eighth Amendment jurisprudence do not mean that Justices and judges do not still root their First and Eighth Amendment analyses in their own methods of constitutional interpretation. The faint-hearted originalist Justice Scalia, for example, routinely discusses the original meaning of the Punishments Clause in his opinions in these types of cases. ${ }^{101}$

Although the Court's approaches in obscenity and Punishments Clause cases are similar in that they address moral questions and account for society's changing values, ${ }^{102}$ the Court probes these notions of cruelty and obscenity differently in these varying contexts. In

98. See id. at 419.

99. See id. at xix-xx (explaining that the Court's reliance on different methods of interpretation often does not dictate the results the Court reaches).

100. Trop v. Dulles, 356 U.S. 86, 101 (1958) (plurality opinion); see also supra text accompanying note 15 .

101. See, e.g., Baze v. Rees, 553 U.S. 35, 88 (2008) (Scalia, J., concurring) (citing in support of the constitutionality of the death penalty the fact that "[t]he same Congress that proposed the Eighth Amendment also enacted the Act of April 30, 1790, which made several offenses punishable by death"); Roper v. Simmons, 543 U.S. 551, 608 (2005) (Scalia, J., dissenting) (stating that the majority's opinion, which held unconstitutional the execution of juvenile offenders, reaches an implausible result by failing to properly rely on the original meaning of the Eighth Amendment and instead relying on the evolving standards of decency and concluding that "the Constitution has changed").

102. In addition to resting on moral determinations and directly appealing to evolving constitutional standards, First Amendment obscenity and Eighth Amendment Punishments Clause jurisprudence share "a special historical tie" because the horrific punishments that prompted the 1689 English Bill of Rights prohibition on cruel and unusual punishments, which in turn inspired the Founders to place the nearly identical prohibition in our own Bill of Rights, were inflicted on individuals criticizing the British government. AKHIL REED AMAR, THE BILL OF RIGHTS: CREATION AND RECONSTRUCTION 82 (1998). For example, it was not uncommon in early Britain for political dissenters convicted of treason to "be hanged by the neck," be cut down while still alive, have their "privy-members . . . cut off," and have their bowels removed and burned. See id. Then, the dissenters, who would still be alive, would have their heads cut off, their bodies cut into quarters, and then these pieces disposed of. See id. 
criminal Punishments Clause cases, ${ }^{103}$ courts consider the issue of cruelty-the moral question involved - to be a question of law. ${ }^{104}$ Accordingly, courts take it upon themselves to determine whether a

103. Interestingly, the issue of cruel and unusual punishment is treated as a mixed question of law and fact for the jury to decide in civil 42 U.S.C. $\S 1983$ cases. An example model jury instruction for such a claim provides that the plaintiff has established excessive use of force under the Eighth Amendment if he has proved all of the following elements:

First, the defendant [here describe an act such as "struck, hit, or kicked"] the plaintiff, and

Second, the use of such force was excessive and applied maliciously and sadistically for the very purpose of causing harm; [and not in a good faith effort to achieve a legitimate purpose;] and

Third, as a direct result, the plaintiff was damaged, and

[Fourth, the defendant was acting under color of state law.]

In determining whether the force[, if any,] was excessive, you must consider such factors as the need for the application of force, the relationship between the need and the amount of force that was used[,] [and] the extent of the injury inflicted[, and whether the force was used to achieve a legitimate purpose or wantonly for the very purpose of causing harm]. "Maliciously" means intentionally injuring another without just cause or reason. "Sadistically" means engaging in extreme or excessive cruelty or delighting in cruelty.

If any of the above elements has not been proved, then your verdict must be for the defendant.

Manual of Model Civil Jury Instructions for the District Courts of the Eighth CIRCUIT $\S 4.30$ (2011), available at $\mathrm{http}: / / \mathrm{www}$.juryinstructions.ca8.uscourts.gov/civ_manual_2 011.pdf.

104. See, e.g., State v. Mata, 745 N.W.2d 229, 267 (Neb. 2008) ("The ultimate issue, whether electrocution violates the constitutional prohibition against cruel and unusual punishment, presents a question of law."); State v. Berhanu, 724 N.W.2d 181, 183 (S.D. 2006) ("Whether a sentence is cruel and unusual in violation of our state and federal constitutions is a question of law reviewed de novo."); State v. Hahn, 618 N.W.2d 528, 530 (Wis. 2000) (stating that whether a punishment violates the Eighth Amendment is a "question of law"); State v. Lee, 439 S.E.2d 547, 571 (N.C. 1994) ("Whether a sentence constitutes cruel or unusual punishment is a question of law and is therefore not a question to be resolved by a jury."). But cf. State v. Gomez, 235 P.3d 1203, 1207-10 (Kan. 2010) (suggesting that, after Graham v. Florida, $130 \mathrm{~S}$. Ct. 2011 (2010), Eighth Amendment categorical questions are questions of law whereas Eighth Amendment term-of-years questions may not so clearly be pure questions of fact); State $v$. Webb, 750 A.2d 448, 453 (Conn. 2000) (describing the cruel and unusual punishment issue as "a mixed question of law and fact," but concluding that it is "subject to independent review by [the] court" and that the appellate court has "plenary review of the trial court's conclusions of law ... and the ultimate question of the constitutionality of [the punishment]" in this context (citation omitted)). As suggested earlier, it is really often the question of cruelty and unusualness that the Court addresses and thus treats as a matter of law. Cf. supra text accompanying notes $62-66$. 
punishment is unconstitutionally cruel and unusual. ${ }^{105}$ In contrast, in obscenity cases, courts consider the moral questions-whether the work appeals to the prurient interest, describes sexual conduct in a patently offensive way, and lacks serious value-to be mixed ones of law and fact. ${ }^{106}$ Accordingly, in cases in which the defendant has elected to have a jury trial, the jury resolves these important First Amendment questions. ${ }^{107}$ Thus, a jury will assess the local community's standards on whether the work appeals to the prurient interest and describes sexual conduct in a patently offensive way. It will also assess the national community's standards regarding the value of the work. The jury's focus on the facts in assessing these issues suggests that the jury's determinations will be tailored to the specific case at bar, achieving a measure of individualization. Because the moral question of cruelty in the Punishments Clause context is instead often determined as a question of law at the appellate level, it cannot be similarly factfocused, and the same measure of individualization cannot be reached in this context. This perhaps explains why the Supreme Court has been moving toward a more categorical approach in its Punishments Clause

105. See, e.g., Berhanu, 724 N.W.2d at 186 (concluding that the defendant's "argument that his sentence amounts to cruel and unusual punishment is without merit"); Hahn, 618 N.W.2d at 530, 536-37 (concluding that Wisconsin's "persistent repeater penalty enhancer," as applied, does not violate the Eighth Amendment).

106. See Miller v. California, 413 U.S. 15, 26 (1973) (stating that "[i]n resolving the inevitably sensitive questions of fact and law" in the obscenity context, the Court "must continue to rely on the jury system"); George C. Christie, Judicial Review of Findings of Fact, 87 Nw. U. L. REV. 14, 38-39 (1992) (explaining that determining whether a work is obscene is a "mixed question[] of law and fact"); J. Wilson Parker, Free Expression and the Function of the Jury, 65 B.U. L. REv. 483, 508 (1985) (explaining that lower courts determine community standards in the obscenity context as "a mixed question of law and fact"). The Court has muddied the waters somewhat by more recently referring to the serious value question as a question of law, see, e.g., Ashcroft v. ACLU, 535 U.S. 564, 579 (2002), but it seems that the Court, in suggesting this, was referring to the fact that serious value is a mixed question of law and fact and that there is perhaps a greater role for appellate court review with respect to the serious value prong. See Reno v. ACLU, 521 U.S. 844, 873 (1997) ("This 'societal value' requirement... allows appellate courts to impose some limitations and regularity on the definition by setting, as a matter of law, a national floor for socially redeeming value."); see also Ashcroft, 535 U.S. at 579 (quoting Reno, 521 U.S. at 873). Today, lower courts still treat the serious value prong as a mixed question of law and fact for the jury.

107. See Miller, 413 U.S. at 30. For example, model jury instructions in Florida lay for jurors the three-prong Miller test and also provide them with definitions of "prurient interest" and "patently offensive." See Standard Jury Instructions for Criminal Cases $\S 24.1$, Florida S. Ct., available at http://www.floridasupremecourt.org/jury_instructions/instructions.shtml (last visited Mar. 18, 2012). Similarly, the model jury instructions used in Connecticut provide jurors with the Miller test requirements and also define for them various terms to more easily apply the test to the facts at hand. See Criminal Jury Instructions $\S 7.4-1$, State of Conn. Jud. Branch, Dec. 1, 2007, available at http://www.jud.ct.gov/ji/criminal/part7/7.4-1.htm. 
adjudications; ${ }^{108}$ it is not well situated to make fact-intensive Eighth Amendment determinations when relying on trial court records that may not have even addressed the issue.

Along with the increased individualization in the First Amendment context comes a lesser degree of uniformity on the matter of obscenity throughout the nation, which some scholars have bemoaned under the Miller jury decisionmaking standard. ${ }^{109}$ One scholar has explained that the Constitution symbolizes our collective values as a nation, and permitting these values to vary among communities undermines "respect for and confidence in the document" and creates "[u]ncertainty and discontent." 110 Another has reasoned that the values of "choice and diversity" that are embraced by the Miller standard are not desirable "when it comes to fundamental rights" because these rights are "supposed to be enjoyed equally by all citizens." concerns, however, scholars have argued that such "geographical constitutional nonuniformity" is valuable in our system and is not uncommon under our Constitution. ${ }^{112}$ As Professor Mark Rosen has articulated, political liberalism dictates that some communities "be permitted to opt out of the general culture and govern themselves subject to only minimal constraints." 113 To deny these subcultures the ability to self-govern so that they can self-actualize is to deprive them of their basic liberties. ${ }^{114}$ In addition to uniformity concerns, there is the fear that allowing local juries to determine constitutional norms - as in the obscenity context-undercuts the purpose of the Bill of Rights to

108. See supra text accompanying notes $39-47$.

109. See, e.g., Clay Calvert, Personalizing First Amendment Jurisprudence: Shifting Audiences \& Imagined Communities to Determine Message Protection in Obscenity, Fighting Words, and Defamation, 20 U. FLA. J.L. \& PUB. POL'Y 439, 443 (2009) (stating that such nonuniformity "obliterates the notion of equality in First Amendment application"); Adam Winkler, Free Speech Federalism, 108 MICH. L. REV. 153, 183 (2009) (questioning the propriety of a standard that results in nonuniformity).

110. Leonard G. Ratner, Majoritarian Constraints on Judicial Review: Congressional Control of Supreme Court Jurisdiction, 27 VILL. L. REV. 929, 940-41 (1982).

111. Winkler, supra note 109 , at 183.

112. Mark D. Rosen, Our Nonuniform Constitution: Geographical Variations of Constitutional Requirements in the Aid of Community, 77 TEX. L. REV. 1129, 1132-33, 1149-66 (1999) (asserting that "geographical nonuniformity of constitutional requirements and proscriptions is a mainstay of American constitutionalism"); see also, e.g., Angela R. Riley, Good (Native) Governance, 107 CoLUM. L. REV. 1049, 1065 (2007) (arguing that "Good Native governance requires the freedom of exit, which has long been considered 'a bedrock liberal value"').

113. Mark D. Rosen, The Outer Limits of Community Self-Governance in Residential Associations, Municipalities, and Indian Country: A Liberal Theory, 84 VA. L. REV. 1053, 1056 (1998).

114. See id. at 1089-1106. To be sure, Professor Mark Rosen's assertion refers to the selfgovernment of particular cultural groups, such as the Mormons or the Oneida, see id. at 106389 , but his argument could be easily extended to the local communities represented by juries. 
protect minorities from the tyranny of majorities. Indeed, the Miller standard is "patently majoritarian" by virtue of its ascertainment by a jury applying primarily community standards. ${ }^{115}$ The concern of an overreaching majority can be traced back to at least James Madison's outline of checks and balances in The Federalist No. 51, where he stated that "[i]t is of great importance in a republic not only to guard the society against the oppression of its rulers, but to guard one part of the society against the injustice of the other part."116 This view of the structure of our federal government has been widely adopted with respect to the role of the Bill of Rights. ${ }^{117}$ For example, in West Virginia State Board of Education v. Barnette, Justice Robert Jackson notably asserted that " $[t]$ he very purpose of a Bill of Rights was to withdraw certain subjects from the vicissitudes of political controversy, to place them beyond the reach of majorities."118

It is questionable whether leaving the question of obscenity to judges rather than juries would remedy this majoritarian concern. As Professor Barry Friedman and others have argued, courts in general are "relatively majoritarian."119 Judicial decisions rely on majoritarian sources such as the state polling that we see in the Punishments Clause context $^{120}$ and vague references to democratic or American values. ${ }^{121}$ Further, the results embodied in judicial decisions-in even the most controversial cases-have generally received a majority, or at least a significant plurality, of public support. ${ }^{122}$ And the judiciary is held

115. See Barry Friedman, Dialogue and Judicial Review, 91 MiCH. L. REV. 577, 605 n.136 (1993).

116. The Federalist No. 51 (James Madison).

117. See, e.g., Michael J. Klarman, Rethinking the Civil Rights and Civil Liberties Revolutions, 82 VA. L. REV. 1, 1 (1996); LAURENCE H. TRIBE, AMERICAN CONSTITUTIONAL LAW 583 (1978) (stating that the judicial branch has the role of "protect[ing] dissenters from a majority's tyranny").

118. 319 U.S. 624, 638 (1943); see also, e.g., Bivens v. Six Unknown Named Agents of Fed. Bureau of Narcotics, 403 U.S. 388, 407 (1971) (Harlan, J., concurring) (stating that, although "legislatures are ultimate guardians of the liberties and welfare of the people in quite as great a degree as the courts ... the Bill of Rights is particularly intended to vindicate the interests of the individual in the face of the popular will as expressed in legislative majorities" (citation omitted)); Akhil Reed Amar, The Bill of Rights as a Constitution, 100 YALE L.J. 1131, 1132 (1991) (stating that the dominant modern approach to reading the Bill of Rights is to view it as "vest[ing] individuals and minorities with substantive rights against popular majorities").

119. Friedman, supra note 115, at 586. Professor Friedman notes that it would be difficult to determine that courts are actually majoritarian, due in part to the difficulty of whether the government, itself, is actually majoritarian. See id. Professor Friedman instead asserts that "courts do not trump majority will, or remain unaccountable to majority sentiment, nearly to the extent usually depicted." Id. He claims that, "[m]easured by a realistic baseline of majoritarianism, courts are relatively majoritarian." Id.

120. See supra notes 17-18 and accompanying text.

121. See Friedman, supra note 115 , at 590-607.

122. See id. at 607-09. Again, Professor Friedman qualifies his assertion with the caveat 
accountable to the majority through either elections or political appointment, which is also majoritarian in nature. ${ }^{123}$

Even though majoritarianism may be a concern with the work of both judges and juries, the history of the Bill of Rights suggests that critics have overstated this issue. In juxtaposition to commentators' emphasis on the countermajoritarian function of the document, examining the legal and political landscapes during the time of the Founding indicates that the original purpose of the Bill of Rights was not to "vest individuals and minorities with substantive rights against popular majorities," populism, federalism, and local autonomy that were already enshrined in the Constitution prior to the ratification of the Bill of Rights. ${ }^{25}$ The drafting of the Bill of Rights was prompted by the Anti-Federalists' concern that the framing of the Constitution presaged a loss in state sovereignty. ${ }^{126}$ Although many of the Anti-Federalists conceded that there was a need for a stronger federal government, they were concerned that the Constitution failed to limit federal powers and provided the scaffolding for an overreaching and tyrannical federal government. ${ }^{127}$ The Bill of Rights was proposed to safeguard state sovereignty and to entrust the states to protect their individual citizens' liberties. ${ }^{128}$

that, "[a]s with legislatures, precisely measuring the congruity between judicial and public views is difficult." Id. at 607 . He also provides the interesting example that "the Court seems to have followed [public opinion]" where the death penalty is at issue. Id. at 608. Although the Court's quintessential opinion in this area, Furman v. Georgia, 408 U.S. 238, 239-40 (1972), in which the court struck down the nation's death penalty statutes, "appears not to have garnered majority support," Professor Friedman explains that the case "was decided at a time when public support for the death penalty was near its lowest point ever." Id. at 608-09. It "thus kicked off an experiment-a test of American sentiment," and "[a]s polls have increasingly show[n] stronger support for the death penalty, the Court has eliminated procedural hurdles to its imposition." Id. at 609 .

123. See Friedman, supra note 115 , at 609-14. Professor Friedman emphasizes that it is the judiciary as a whole, rather than individual judges, that are most important "for matters of serious public moment." Id. at 613 .

124. AMAR, supra note 102 , at xii.

125. See id. at xii-xiii, 97 (introducing his interpretation that the Bill of Rights was originally meant to empower popular majorities and deploy the "organizational structure and democratic self-governance" of the Constitution); see also Arthur E. Wilmarth, Jr., The Original Purpose of the Bill of Rights: James Madison and the Founders' Search for a Workable Balance Between Federal and State Power, 26 AM. CRIM. L. REV. 1261, 1262 (1989) ("[T]he historical record establishes that the Bill of Rights was originally intended to protect the states and their respective citizens from undue federal interference.").

126. See Wilmarth, supra note 125 , at 1281 (explaining that the purpose of drafting the Bill of Rights was "to secure the people's liberty" by preserving state sovereignty).

127. See id. at $1276-84$.

128. See id. at 1281. Professor Arthur E. Wilmarth, Jr. has explained that: 
The primary tool that the Bill of Rights employs to safeguard state sovereignty is that of the local jury. "[A]t the heart of the Bill of Rights," 129 the jury is found in the Fifth Amendment's provision for a grand jury in certain criminal cases, ${ }^{130}$ the Sixth Amendment's guarantee of a petit jury in criminal cases, ${ }^{131}$ and even the Seventh Amendment's right to be tried by a jury in particular civil cases. ${ }^{132} \mathrm{~A}$

The Antifederalists focused on the reservation of state powers and rights for two reasons. First, the states, and not the distant federal government, were considered to be the true guardians of the people's rights. Second, the Articles of Confederation had followed the proper federal policy by reserving to the states all questions regarding individual liberties and all other powers not expressly granted to the Confederation Congress.

Id.

129. See AMAR, supra note 102 , at $83,96,108$ (stating that "[j]uries ... were at the heart of the Bill of Rights"; that "[i]f we seek a paradigmatic image underlying the original Bill of Rights, we cannot go far wrong in picking the jury"; and that "[j]uries stood at the center of the original Bill of Rights").

130. See U.S. CONST. amend. V ("No person shall be held to answer for a capital, or otherwise infamous crime, unless on a presentment or indictment of a Grand Jury, except in cases arising in the land or naval forces, or in the Militia, when in actual service in time of War or public danger...."); see also AMAR, supra note 102, at 83 ("The Fifth Amendment safeguarded the role of the grand jury ....").

131. See U.S. CONST. amend. VI ("In all criminal prosecutions, the accused shall enjoy the right to a speedy and public trial, by an impartial jury of the State and district wherein the crime shall have been committed, which district shall have been previously ascertained by law ...."); see also AMAR, supra note 102, at 83 (stating that the Sixth Amendment safeguarded the role of "the criminal petit jury"). Of course, the meaning of the Bill of Rights might be interpreted differently today when its provisions are applied to states through the Fourteenth Amendment, cf. Amar, supra note 124, at 1134-36 (explaining how the Supreme Court's focus on striking down state, rather than federal, laws as violating the Constitution has obscured the Bill of Rights' original focus on "protecting a majority of the people from a possibility unrepresentative government" and redirected it toward "protecting vulnerable minorities from dominant social majorities"), which was ratified during a time when the power of juries was greatly diminished, see supra text accompanying notes 156-76. To this extent, some readers may find the early practices of juries irrelevant to proper Eighth Amendment interpretations, applications, and practices. Several Supreme Court Justices, though, often invoke the original meaning or understanding of the Eighth Amendment in analyzing Punishments Clause issues. See, e.g., Graham v. Florida, 130 S. Ct. 2011, 2044 (2010) (Thomas, J., dissenting) (criticizing the majority for departing from the original meaning of the Punishments Clause in interpreting it to proscribe grossly disproportionate punishments); Kennedy v. Louisiana, 554 U.S. 407, 469 (2008) (Alito, J., dissenting) (disagreeing with the majority's determination that executing an individual for the crime of child rape is unconstitutional in part because the "holding is not supported by the original meaning of the Eighth Amendment"); Baze v. Rees, 553 U.S. 35, 88 (2008) (Scalia, J., concurring) (citing in support of the constitutionality of the death penalty the fact that "[t]he same Congress that proposed the Eighth Amendment also enacted the Act of April 30, 1790, which made several offenses punishable by death").

132. See U.S. ConST. amend. VII ("In Suits at common law, where the value in controversy shall exceed twenty dollars, the right of trial by jury shall be preserved, and no fact tried by a 
body consisting of ordinary citizens, the jury was meant to protect individuals from an overreaching new federal government and its brigade of judges and prosecutors. ${ }^{33}$ After all, the Founding generation had experienced firsthand the perils of a too-powerful government, and this is the reason the Founders had drafted the Declaration of Independence just over a decade earlier. ${ }^{134}$

State sovereignty was of utmost concern to the Anti-Federalists in the area of criminal law, ${ }^{135}$ and the local jury was therefore of particular importance in this context. The Bill of Rights' limitation on searching citizens' homes, ensuring a right against self-incrimination, and guaranteeing the right to trial in criminal cases, among other rights, were all designed to make it difficult for the federal government to interfere with state systems of criminal justice. ${ }^{136}$ It therefore makes sense that these limitations are complemented by the Bill's guarantees of criminal juries in both the Fifth and Sixth Amendments. ${ }^{137}$ In

jury, shall be otherwise re-examined in any Court of the United States, than according to the rules of the common law."); see also AMAR, supra note 102, at 83 (stating that the Seventh Amendment safeguarded the role of "the civil jury").

133. See AMAR, supra note 102 , at 84 (stating that "the jury played a leading role in protecting ordinary individuals against governmental overreaching" and that "the jury could thwart overreaching by powerful and ambitious prosecutors and judges").

134. See generally THE DECLARATION OF INDEPENDENCE (U.S. 1776) (setting forth the colonists' complaints against the British crown).

135. See Michael J. Zydney Mannheimer, Cruel and Unusual Federal Punishments 50 (Aug. 11, 2011) (unpublished manuscript), available at http://ssrn.com/abstract=1875868 ("A primary concern ... of the Anti-Federalists was the continuing prerogative of the States to set their own parameters of crime and punishment.").

136. See id. at 53 ("The point of the criminal procedure protections of the Bill of Rights was not to reliably convict the guilty and acquit the innocent but to make it extremely difficult for the federal government to use the machinery of criminal justice at all."); George C. Thomas III, When Constitutional Worlds Collide: Resurrecting the Framers' Bill of Rights and Criminal Procedure, 100 MicH. L. REV. 145, 160 (2001) ("The principal concern in the Bill of Rights was not to protect innocent defendants. The Framers instead intended to create formidable obstacles to federal investigation and prosecution of crime.").

137. See supra notes 130-131 and accompanying text; see also Mannheimer, supra note 135 , at 54 (opining that juries are central to the Bill of Rights because they are better than judges at "channeling the moral sensibilities of the community in order to nullify unjust laws, judging the character of their neighbors as defendants, accusers, and witnesses, adapting generallyapplicable law to idiosyncratic local conditions, and providing an opportunity for active civic engagement by the ordinary citizen"). One might argue that the specific mention of juries in the Fifth and Sixth Amendments, and the absence of such a reference in the Eighth Amendment, suggests that juries are not the appropriate decisionmakers in the Eighth Amendment context. The Fifth and Sixth Amendments, however, provide broad jury rights that could be seen to extend beyond those specific Amendments. See U.S. CONST. amend. V; U.S. CONST. amend. VI. Moreover, the First Amendment, pursuant to which the jury has been integrated into decisionmaking, also does not specifically reference juries. See U.S. ConsT. amend. I. Nor does the Bill of Rights suggest whether judge or jury is the default decisionmaker. However, history suggests that juries were originally charged with making both factual and legal determinations. 
essence, the jury's role of acting as a bulwark between the people of the states and the federal government was essential to the conception of criminal law under the Constitution and its Amendments.

Not only does the Anti-Federalists' focus on safeguarding state sovereignty and the jury relate to the majoritarian concern of the prominent role of the jury under Miller, but it also relates to critics' concerns of nonuniformity under jury determinations of constitutional questions. $^{138}$ Due to the importance of the jury under the AntiFederalists' vision, some nonuniformity in constitutional determinations was anticipated, and even embraced by some. ${ }^{139}$ The colonists had become accustomed to variations in the law, and, as one commentator of this era proclaimed, it would be "[i]n vain [to] attempt ... to establish an uniform authority and obligation of the ... law." 140 The Anti-Federalists did not anticipate that the Bill of Rights would bring uniformity to this kaleidoscopic legal landscape-even on issues of constitutional magnitude. ${ }^{141}$

This history of the Bill of Rights, together with the fact that jury determinations are not dependent on the moral whims of generally unrepresentative judges, suggests that the Miller approach of allowing juries to determine constitutional moral questions has merit. This raises the question, then, of why moral issues are characterized as questions of law in the Punishments Clause context but as mixed questions of law and fact in the obscenity context. Perhaps a look at the history of how this country has addressed questions of law versus questions of fact and mixed questions of law and fact will provide some insight into this distinction.

See infra Part IV.

138. See supra text accompanying notes 109-111.

139. See Mannheimer, supra note 135 , at 55.

140. Id. at 60-61 (quoting ST. GEORGE TUCKER, BLACKSTONE'S COMMENTARIES: WITH NOTES OF REFERENCE, TO THE CONSTITUTION AND LAWS, OF THE FEDERAL GovernMENT OF THE UNITED STATES; AND OF THE COMMONWEALTH OF Virginia, at app. E 405 (1803)). In 1812, the Supreme Court characterized the common law as "varying in every state in the Union." United States v. Hudson, 11 U.S. (7 Cranch) 32, 33 (1812).

141. Further, as Professor Akhil Amar points out, this same uniformity concern could be expressed with respect to Article III judicial review of 1800. See AMAR, supra note 102, at 101. "Through its power to make exceptions to the Supreme Court's appellate jurisdiction, Congress could vest the last word in constitutional cases in lower federal courts who, like juries, might disagree among themselves.". Id. Moreover, "under the Judiciary Act of 1789, the Supreme Court lacked jurisdiction to hear [the famous Callender case, which dealt with the issue of whether a jury has the right to refuse to follow a law it deems unconstitutional] ... [t] he most important constitutional issue of the Federalist era." Id. at 98-101. 


\section{THE HISTORICAL ROLE OF THE JURY AND ITS DEMISE}

Historically, juries have been trusted to decide issues like Eighth Amendment cruelty that we might today consider questions of law. ${ }^{142}$ The American criminal law system derived, in large part, from its English ancestor. ${ }^{143}$ The English jury was formally a body charged with determining the facts of a case. ${ }^{44}$ But as one commentator explains, English jurors often manipulated the facts of a case to acquit defendants whom the jurors determined were not deserving of the harsh punishments of the day. ${ }^{145}$ The Founders actually provided American juries with greater formal powers than the English jurors enjoyed. ${ }^{146}$ Early American jurors were not only charged with fact-finding, as their English ancestors were, but they were also informed that they had the power, and the right, to determine the law in the case at hand. ${ }^{147}$ For example, in the 1794 U.S. Supreme Court case of Georgia v. Brailsford, ${ }^{148}$ the Court explicitly stated that a jury has "a right ... to determine the law as well as the fact in controversy.'

The American jury's power began to wane somewhat around the beginning of the nineteenth century. ${ }^{150}$ Prior to this time, American society was rather simple and the reigning law relatively provincial. ${ }^{151}$ Americans drew much of their law from England, but written legal opinions were practically nonexistent, ${ }^{152}$ and there were no treatises on American law until 1803. ${ }^{153}$ At least one commentator has described

142. See Mark DeWolfe Howe, Juries as Judges of Criminal Law, 52 HARV. L. REV. 582, 583-84 (1939).

143. See Chris Kemmitt, Function Over Form: Reviving the Criminal Jury's Historical Role as a Sentencing Body, 40 U. MiCH. J.L. REFORM 93, 101 (2006) (stating that "the role of American juries was substantially influenced by eighteenth century British practices," but noting that "the colonists did not adopt Anglo practices wholesale").

144. See id. at 98.

145. See id. at $98-100$.

146. See id. at 103-07; Matthew P. Harrington, The Law-Finding Function of the American Jury, 1999 WIS. L. REV. 377, 387 ("In many ways, the colonial jury was vested with a lawfinding function greater than that possessed by its English counterpart.").

147. See Kemmitt, supra note 143, at 102-04, 106-07.

148. 3 U.S. 1 (Dall.) (1794).

149. Id at 4 . This historical antecedent should not be confused with the still-present phenomenon of jury nullification. Jurors today retain the power to interpret the law in accordance with their own beliefs, but they arguably lack the right to do so, whereas the Brailsford Court provided juries with not only the power to interpret law, but also the right to do so. See Jonathan Lahn, The Demise of the Law-Finding Jury in America and the Birth of American Legal Science: History and Its Challenge for Contemporary Society, 57 CLEV. ST. L. REV. 553, 556, 559 (2009).

150. See Lahn, supra note 149 , at 556.

151. See id. at 569.

152. Pennsylvania, however, had been publishing legal opinions since 1806. See id. at 570 .

153. See id. at 554 n.2. 
this period as a time of anarchy within the legal system that caused a growing mistrust in the tyrannical powers of the democratic majorities embodied in juries. ${ }^{154}$ This, it has been said, led to the deterioration of the jury's power in determining questions of law. ${ }^{155}$ Another scholar has argued that this period was not anarchy but instead just constituted a different kind of rule of law-a more "ephemeral" law that was the product of juror consensus in a particular case. ${ }^{156}$ Regardless, the legal milieu in America soon began to change. Influenced by William Blackstone's Commentaries on the Laws of England and the focus on values associated with the rationality and scientific reasoning of the Enlightenment, American legal thinkers began working to create a more systematized legal landscape. ${ }^{157}$ This involved the drafting of written legal opinions and treatises, as well as the promulgation of rules of evidence and procedure. ${ }^{158}$ Along with this growing complexity of the legal field, lawyers and judges began increasingly taking advantage of legal training and education. ${ }^{159}$ This led to a more professionalized legal environment, and judges and lawyers, who had become competent experts in the field, began taking greater control in the courtroom. ${ }^{160}$ As the complexity of the law grew, the average citizen gradually became less able to understand the law and had to instead rely on these legal professionals. ${ }^{161}$ With this growing inability of lay individuals to understand the law, trust in the average juror declined as well. ${ }^{162}$ Not

154. See Letter from James Kent to Thomas Washington, in MEMOIRS AND LETTERS OF JAMES KENT 118 (William Kent ed., 1898) (observing that "English authority did not stand very high in those early feverish times"); see also William E. NELSON, AMERICANIZATION OF THE COMMON LAW: THE IMPACT OF LEgAL CHANGE ON MASSACHUSETTS SOCIETY, 1760-1830, at 8 (1975) ("As unity and stability broke down near the turn of the century, the jury system began to function less efficiently and with less certainty and predictability."); Lahn, supra note 149, at 567.

155. See NELSON, supra note 154 , at 8 (noting that "[t]he needs of business entrepreneurs ... changed the legal system by depriving juries in civil cases of their right to decide the law"); Harrington, supra note 138, at 397-98, 414-15, 427-28 (describing colonists' "desire to escape the vagaries of state court juries" and gain some stability within both the civil and criminal law); Lahn, supra note 149 , at 567-68.

156. See Lahn, supra note 149 , at 567.

157. See id. at 570-72.

158. See id.

159. See Mark P. Gergen, The Jury's Role in Deciding Normative Issues in the American Common Law, 68 Fordham L. Rev. 407, 419-20 (1999); Matthew Tulchin, Note, An Analysis of the Development of the Jury's Role in a New York Criminal Trial, 13 J.L. \& PoL'Y 425, 46366 (2005).

160. See Harrington, supra note 146 , at 380,432 ; Tulchin, supra note 159 , at $463-66$.

161. See Tulchin, supra note 159 , at $463-66$.

162. See Albert W. Alschuler \& Andrew G. Deiss, A Brief History of Criminal Jury in the United States, 61 U. CHI. L. REv. 867, 916 (1994); Toni M. Massaro, Peremptories or Peers?Rethinking Sixth Amendment Doctrine, Images, and Procedures, 64 N.C. L. REV. 501, 509 (1986) 
only did jurors lack the professionalized knowledge of law, but as society grew more confident in the newly formed republican government of the United States, jurors were viewed as undermining a government that was more representative of the people. ${ }^{163}$ Jurors were no longer seen as a necessary bulwark between individuals and their government. ${ }^{164}$ Moreover, the growth in America during this era has been said to have caused societal breakdown in terms of the people's unity on issues such as ethics and economics. ${ }^{165}$ So not only were jurors viewed as incompetent and untrustworthy, but the inconsistency among different jurors' values led to significant unpredictability in jury verdicts, which was understood as harmful to business interests and the country's economic growth. ${ }^{166}$ As a result, American industrialists exerted pressure to constrain juries' powers.

Scholars dispute the extent to which any of these, or other, ${ }^{167}$ factors contributed to the demise of the jury's power in the United States, but it is undisputed that before the century's end, the jury had lost a significant quantum of its original power. In 1895, the Supreme Court officially divested the federal jury of its right to decide legal questions. ${ }^{168}$ In Sparf v. United States, it stated that:

Public and private safety alike would be in peril, if the principle be established that juries in criminal cases may, of right, disregard the law as expounded to them by the court and become a law unto themselves. Under such a system, the principal function of the judge would be to preside and keep order while jurymen, untrained in the law, would determine questions affecting life, liberty, or property according to such legal principles as in their judgment were

163. See NELSON, supra note 154 , at 8.

164. See Harrington, supra note 146, at 438.

165. See id. As Professor William Nelson stated:

[A] jury system in which juries have power to find law can function only in a society with substantial ethical unity and economic and social stability. As unity and stability broke down near the turn of the century, the jury system began to function less efficiently and with less certainty and predictability. Certainty and predictability, however, were the very qualities that business entrepreneurs needed most in order to rationally allocate resources for economic growth, and they accordingly began to complain about the jury system's inefficiencies. As a result, juries lost their power to find law.

Id.

166. See id.

167. One scholar argues that the passage of the Civil War Amendments was also responsible for transforming a law-and-fact-deciding jury into one with the right to decide only questions of fact. See Tulchin, supra note 159, at 468, 470-72.

168. See Sparf v. United States, 156 U.S. 51, 102 (1895). 
applicable to the particular case being tried....[T]he enforcement of the law against criminals and the protection of citizens against unjust and groundless prosecutions, would depend entirely upon juries uncontrolled by any settled, fixed, legal principles.... When that occurs our government will cease to be a government of laws, and become a government of men. ${ }^{169}$

Today, it is widely accepted that courts, rather than juries, are to determine questions of law, and juries are to determine questions of fact and mixed questions of law and fact. ${ }^{170}$

Although the American jury's power has waned over the last century, the Supreme Court has recently breathed new life into the role of the criminal jury. In its 2000 case of Apprendi v. New Jersey, ${ }^{171}$ the Court upended decades of criminal sentencing practices by holding that it is unconstitutional for a judge to base an offender's criminal sentence on a factor determined by the judge by a preponderance of the evidence instead of by a jury by proof beyond a reasonable doubt (when the offender's trial was a jury trial). ${ }^{172}$ The Court stated that "[o]ther than the fact of a prior conviction, any fact that increases the penalty for a crime beyond the prescribed statutory maximum must be submitted to a jury, and proved beyond a reasonable doubt."173 It reasoned that the jury exists to "guard against a spirit of oppression and tyranny on the part of rulers, and as the great bulwark of [our] civil and political liberties."174 Thus anything less than a procedure ensuring that a sentence is based on only jury-found facts would be "an unacceptable departure from the jury tradition that is an indispensable part of our criminal justice system." 175 In United States $v$. Booker, ${ }^{176}$ the Court applied this landmark decision to hold unconstitutional the Federal Sentencing Guidelines as they had been applied for nearly twenty years. ${ }^{177}$ This resulted in transforming the once-mandatory Guidelines into a merely

169. Id. at 101-03.

170. See, e.g., United States v. Gaudin, 515 U.S. 506, 512 (1995). Despite this modern division of power, juries still retain the power, if not the right, to nullify. See supra note 149.

171. 530 U.S. $466(2000)$.

172. See id. at 491-92.

173. Id. at 490.

174. Id. at 477 (citation omitted) (internal quotation marks omitted).

175. Id. at 497 .

176. 543 U.S. $220(2005)$.

177. See id. at 245,259 (plurality opinion) (determining that the Guidelines must be viewed as advisory rather than mandatory); see also Kate Stith \& Steve Y. Koh, The Politics of Sentencing Reform: The Legislative History of the Federal Sentencing Guidelines, 28 WAKE FOREST L. REV. 223, 228 (1993) (noting that the Federal Sentencing guidelines were promulgated in 1987). 
advisory system. ${ }^{178}$ In finding the mandatory enhancements under the Guidelines unconstitutional, the Court expressed concern that

The effect of the increasing emphasis on facts that enhanced sentencing ranges ... was to increase the judge's power and diminish that of the jury. It became the judge, not the jury, who determined the upper limits of sentencing ... [which resulted in] the jury's finding of the underlying crime [becoming] less significant.

While these cases do not fully restore the American jury to its pre-Sparf power, they have shed light on the importance of the jury to serve as a bulwark between the government and the individual ${ }^{180}$ and, as one scholar has asserted, "open[ed] the possibility of returning the jury to its historical role of judging not only the facts of the case, but the meaning of the law as applied to a particular defendant."181

\section{Viewing Eighth AMEndment CRUelty as a MiXed Question of LAW AND FACT}

The reasons for the general dilution of the jury's power in the nineteenth century do not explain why the First Amendment question of obscenity remained with the jury but the Eighth Amendment question of cruelty was diverted to judges. The professionalization of law and the complexity of legal questions are not any more enhanced in the Eighth Amendment cruelty context such that it was necessary to shift this constitutional moral question to expert judges. In fact, one might conclude that if either question is more complex, it is the First Amendment question of obscenity. While there is no clear legal formula for determining Eighth Amendment cruelty in criminal law, ${ }^{182}$ at least in the obscenity context (despite Justice Stewart's diminishment of the issue when he said that he just knows it when he sees $i^{183}$ ) the Miller Court gave a rather specific prescription for identifying obscene material in its three-pronged test of appealing to the prurient interest,

178. Booker, 543 U.S. at 245 .

179. Id. at 236.

180. See id. at 237.

181. Jenny E. Carroll, The Jury's Second Coming, 100 Geo. L.J. (forthcoming 2012) (manuscript at 38), available at http://ssin.com/abstract=1486188. But cf. Ring v. Arizona 536 U.S. 584, 610 (2002) (Scalia, J., concurring) (asserting that the Ring case, in which the Court held that statutorily enumerated aggravating factors subjecting a defendant to the death penalty must be found by a jury, "has nothing to do with jury sentencing").

182. But see Ryan, supra note 26 , at 124,149 (suggesting that motive and method are central to the cruelty inquiry).

183. See Jacobellis v. State, 378 U.S. 184, 197 (1964) (Potter, J., concurring); supra text accompanying note 86 . 
depicting sexual conduct in a patently offensive way, and lacking serious value. ${ }^{184}$ The First Amendment question is thus formulated in a more systematized way, suggesting that if either question should be given to the judge it should be the determination of obscenity rather than cruelty. Just as professionalization seems to be a greater concern in the obscenity context, the lack of competency on the part of jurors would, for the same reason, be more worrisome when jurors are asked to determine the complex issue of obscenity under Miller rather than the simple question of cruelty, which is more intuitive. ${ }^{185}$ Because it is a less complex issue, there should be greater trust in jurors with the moral question of cruelty.

Any trepidation that jurors undermine our representative government should not be greater in the cruelty context than in the obscenity area. In both instances, jurors have the potential to upset legislative enactments, but in both cases, jurors also have the ability to protect individuals from rash and unjust governmental actions. Concerns of tyrannical democratic majorities might similarly be equivalent between obscenity and cruelty questions. In both instances, there is a possibility that juries will react strongly to the unsettling subjects-either explicit or pornographic speech or materials that could be considered obscene on the one hand, or violent or other horrific crimes perpetrated by individuals on the other. One might argue that there is greater concern with respect to impulsive actions taken by juries imposing or reviewing punishments because, often, the public can become easily outraged in response to violent crimes, such as in child rape cases and other cases involving crimes against children. ${ }^{186}$ In some parts of the country, though, the public may become equally inflamed when faced with, for example, images of graphic nudity.

Further, history suggests that the Anti-Federalists' view of the Bill of Rights lauded the jury and viewed it as a necessary bulwark between the government and the people. ${ }^{187}$ The centrality of the jury is, of course, consistent with the original division of labor between judges and juries, where juries were entrusted to resolve questions of law as well as

184. See supra text accompanying notes 87-91.

185. See, e.g., Mary Sigler, Just Deserts, Prison Rape, and the Pleasing Fiction of Guideline Sentencing, 38 ARIZ. ST. L.J. 561, 564 (2006) (recognizing the intuitive aspect of determining what sentence an offender deserves and highlighting the instinctual nature of discerning punishments that are too cruel to be imposed).

186. The recent trial of Casey Anthony, for example, conjured up significant public outrage. See, e.g., Order Establishing Rules Governing Members of the Public, Florida v. Anthony, No. 48-2008-CF-015606-O (Fla. 9th Cir. Ct. 2011), available at http://www.ninth circuit.org/news/High-Profile-Cases/Anthony/Downloads/Order\%20Establishi ng\%20Rules\%20Governing\%20Members\%20of\%20the\%20Public.pdf (limiting access to the courtroom to only those in possession of a "seating pass").

187. See supra text accompanying notes $135-137,174,180$. 
questions of fact and mixed questions of law and fact. Naturally, this greater role on the part of juries suggests less uniformity on these constitutional moral questions, which is related to the nineteenthcentury concern that the breakdown in society resulting from America's continued growth - and the concomitant variation in values among members of the public - would lead to inconsistent and unpredictable jury verdicts. This constitutional nonuniformity, though, as in the First Amendment context, was contemplated and embraced by at least some of the Founding generation. In fact, as one scholar has explained, the "Punishments Clause was understood as imposing common-law constraints on the federal government's power to punish, and ... the common law was understood as varying State by State,... [thus] the Anti-Federalists contemplated that the meaning of 'cruel and unusual' punishments might vary according to the locale." 188 Moreover, the concern of notice to defendants that arises when there is a lack of uniformity in the law is arguably less concerning in the Punishments Clause context than under the Court's obscenity jurisprudence. This results from the fact that, while individuals may rely on legal precedent in ascertaining whether their planned courses of conduct would be considered criminal, research suggests that would-be offenders rely significantly less on what type of punishment they will receive, or whether any imposed punishment will be considered unconstitutionally cruel and unusual, when determining whether to engage in a particular type of conduct. ${ }^{189}$ Eighth Amendment issues are certainly important, in part because they often amount to cases of life or death-such as when the Supreme Court determined that Christopher Simmons, despite receiving a sentence of death for first-degree murder, could not be executed because he was a juvenile when he committed the offense. ${ }^{190}$ But the criminal law literature is rife with accounts of why more is at stake when determining issues of criminal liability than issues of sentencing. After all, in the first instance, we could be dealing with completely innocent individuals. Once an individual has been found guilty, however, he may be deprived of some aspects of his dignity, and he loses some of the constitutional protections to which an innocent individual is entitled. ${ }^{191}$ Therefore, because the First Amendment

188. Mannheimer, supra note 135 , at 74.

189. See Yair Listokin, Crime and (With a Lag) Punishment: The Implications of Discounting for Equitable Sentencing, 44 AM. CRIM. L. REV. 115, 122 (2007). Would-be offenders, like other individuals, likely discount the future. This means that if a sentence is imposed sometime in the future, it has less of a deterrent effect than if it was imposed immediately. Id.

190. See Roper v. Simmons, 543 U.S. 551, 575 (2005).

191. See, e.g., Richardson v. Ramirez, 418 U.S. 24, 54 (1974) (upholding the constitutionality of felony disenfranchisement statutes). Note that I am not suggesting that a convicted person can be deprived of the protections provided by the Eighth Amendment 
question of obscenity constitutes an issue of criminal liability, whereas the Eighth Amendment question of cruelty relates to sentencing, one might conclude that more is at stake in the obscenity context. Accordingly, even if there is a concern about the unpredictability inherent in jury decisions, if it is appropriate to entrust the question of obscenity to a jury, then it would seem to be equally appropriate to trust juries to decide questions of cruelty.

While the reasons for the jury's decline in power do not adequately explain the disparate treatment between constitutional moral decisionmaking in the First Amendment and Eighth Amendment areas, approaching the Eighth Amendment issue as a mixed question of law and fact, just like in the First Amendment context, would curb scholars' existing criticisms of the Court's reliance on its own independent judgment in cruelty determinations. Viewed as a mixed question of law and fact for the jury to resolve, the question of cruelty would no longer be decided by the whims of unrepresentative judges who are often not held accountable to the people. ${ }^{192}$ Many judges confronting Eighth Amendment issues have life tenure and thus may not be directly swayed by public opinion in determining issues of cruelty. Indeed, this isolation of judges is the justification for awarding them life tenure in the first place. ${ }^{93}$ And, while judges are notoriously unrepresentative of either the American public at large or their individual communities, ${ }^{194}$ juries are tailored to be representative of the latter, at least within limits. ${ }^{195}$

Punishments Clause.

192. But cf. Friedman, supra note 115 (arguing that even judges are "relatively majoritarian").

193. See Dan T. Coenen, The Constitutional Case Against Intracircuit Nonacquiescence, 75 MINN. L. REv. 1339, 1406 (1991) (noting that federal judges are provided life tenure and protected against salary reductions so that they are not susceptible to outside influence).

194. See Thompson v. Oklahoma, 487 U.S. 815, 873 (1988) (Scalia, J., dissenting) (describing the Court as a "small and unrepresentative segment of our society"); Harry S. Gerla, The "Reasonableness" Standard in the Law of Negligence: Can Abstract Values Receive Their Due?, 15 U. DAYTON L. REV. 199, 223 (1990) ("Judges are a highly unrepresentative cross section of society. Judges are more predominantly male, white, and wealthy than the body politic as a whole. While juries are perhaps also unrepresentative of their communities, they mirror the characteristics of those communities much closer than do judges.").

195. As Professor Stephen Smith has noted,

jury-selection practices may serve to undermine the degree to which the petit jury is truly representative of the community. The removal of jurors for cause or through peremptory challenges may cause juries to lose some degree of the representativeness they had at the venire stage. Moreover, in capital cases, the controversial but accepted practice of "death qualifying" juries has been shown to result in "hanging juries" that have fewer minorities and women and are significantly more likely to convict and impose the death penalty than other juries. Still, local representativeness is a central idea behind the American conception of criminal juries. 
Moreover, juries are just as competent, if not more competent, to make a decision on this moral question of cruelty, which is a matter of personal values. While the jury's resolution of the issue could equally lack the standards that the Court's application of its independent judgment seems to currently lack, thus rendering it susceptible to the criticism of being suspect in terms of its sociological legitimacy, ${ }^{196}$ this could be remedied through the use of appropriate jury instructions. A jury could be directed, for example, to base its determination of unconstitutional cruelty on matters such as whether the defendant deserves such a harsh punishment, whether similarly situated offenders have received similar punishments, and whether the punishment is likely to deter this offender from committing further crimes or whether it is likely to deter others. ${ }^{197}$ Ultimately, Professor Allen's conclusion that constitutional moral questions should be controlled by society ${ }^{198}$ would be well served by shifting the cruelty question to juries.

Not only would charging juries with resolving cruelty address concerns of anti-democratism and sociological legitimacy, but it would allow cruelty determinations to be more precisely rooted in the facts at hand. ${ }^{199}$ While Eighth Amendment questions are often decided categorically today, ${ }^{200}$ especially in the death penalty context, accounting for the salient facts of Punishments Clause cases would be useful in achieving sufficiently individualized punishments for offenders. Individualization in sentencing has long been held important by many sentencing scholars. Since the advent of the Federal Sentencing Guidelines, they have asserted that the lost individualization of sentencing under the Guidelines is worth protesting. Individualized

Stephen F. Smith, Localism and Capital Punishment, 64 VAND. L. REV. EN BANC 105, 111 (2011).

196. See supra text accompanying note 54 .

197. Cf. Jeffrey Bellin, Is Punishment Relevant After All? A Prescription for Informing Juries of the Consequences of Conviction, 90 B.U. L. REV. 2223, 2233-35 (explaining that informing jurors of the consequences of conviction could inspire the jurors, in the name of justice, to acquit defendants who might otherwise be found guilty). This is just a sampling of some of the factors that may be relevant in the cruelty determination. Whether a defendant deserves the punishment relates to the Court's focus on retribution in resolving Punishments Clause questions, see supra text accompanying note 26 ; whether similarly situated offenders have received similar punishments derives from the Court's noncapital Punishments Clause jurisprudence, see supra text accompanying notes 27-28; and whether the punishment is likely to deter again relates to the Court's focus on the purposes of punishment under its independent judgment analysis, see supra text accompanying note 26 .

198. See supra text accompanying notes 75-76.

199. Cf. generally Henry P. Monaghan, Constitutional Fact Review, 85 CoLUM. L. REV. 229 (discussing the role of constitutional fact review in appellate court decisionmaking).

200. See Graham v. Florida, 130 S. Ct. 2011, 2022-23 (2010) (describing the categorical approach); supra text accompanying notes $41-43,47$. 
sentencing, they have argued, is essential to achieving justice. ${ }^{201}$ Without the context of an offender's individual circumstances, judges and juries cannot impose sentences that are fair and appropriate. ${ }^{202}$ In particular, because the goals of retribution, deterrence, incapacitation, and rehabilitation are at the heart of sentencing, individualization is essential to accurately concentrate punishment on these specific goals. One scholar has explained that individualized factors, such as a defendant's education, are essential to implementing the traditional punishment goals through sentencing and should therefore be central to sentencing inquiries. ${ }^{203}$ For example, "[a] man or woman with no employment prospects or an unstable emotional condition is more likely to return to crime, and thus could be a stronger candidate for incapacitation." 204 Considering that the purposes of sentencing are central not only to imposing a sentence in the first instance, but also to determining whether a punishment is unconstitutionally cruel under the Eighth Amendment, ${ }^{205}$ accounting for these purposes in determining cruelty should similarly involve more detailed and fact-based accounts of how these specific goals could be served by the sentence actually imposed. This approach would advance the Court's directive that, in capital sentencing, juries must be allowed to consider, in all but the rarest cases, mitigating evidence proffered by the capital defendant that bears on the defendant's character, his record, or the circumstances of the crime. ${ }^{206}$

Finally, giving greater power to juries in the resolution of constitutional moral questions such as cruelty is consistent with the Court's recent trend of returning to juries some of the power they lost in the nineteenth century. This shift would further address the Apprendi and Booker Courts' concern of maintaining the jury's role as a guard against government's oppression and as the "great bulwark of [our] civil and political liberties." 207 This could be one step further in returning the jury to its historical prominence. 208

201. See Terence F. MacCarthy et al., Individualized Sentences and Alternatives to Imprisonment, 5 FED. SENT'G REP. 211, 211 (1993).

202. See Charles J. Ogletree, Jr., The Death of Discretion? Reflections on the Federal Sentencing Guidelines, 101 HARV. L. REV. 1938, 1953 (1988) (favoring a "system that ... consider[s] the offender's personal characteristics").

203. See Mark Osler, Uniformity and Traditional Sentencing Goals in the Age of Feeney, 16 FED. SENT'G REP. 253, 254 (2004).

204. Id.

205. See supra text accompanying notes $26,55-60$.

206. See Lockett v. Ohio, 438 U.S. 586, 604 (1978).

207. Apprendi v. New Jersey, 530 U.S. 466, 477 (2000) (citation omitted) (internal quotation marks omitted).

208. See Carroll, supra note 181, at 38; supra text accompanying notes 142-149, 171-182. 


\section{OBVIOUS PRocedural HuRdLES}

Considering that the reasons related to the jury's decline in the nineteenth century are unable to explain the different treatment of the questions of cruelty and obscenity, as well as the promise of individualization that jury determinations would bring to the Punishments Clause area, perhaps procedural differences in obscenity and Punishments Clause cases account for the disparate approaches. Whereas questions of obscenity ordinarily constitute principal issues in a trial, questions of the constitutionality of a punishment under the Eighth Amendment often arise in a slightly different context. Frequently, a defendant who has just been sentenced may directly appeal his sentence and at that time assert that it violates the Eighth Amendment. In some jurisdictions an appeal of a death sentence is even automatic, such as was the case in Atkins. ${ }^{209}$ In contrast, the criminal defendant in Baze v. Rees ${ }^{210}$ pursued his Eighth Amendment claim by requesting a declaration of rights pursuant to state law. ${ }^{211}$ Further, in several jurisdictions a defendant may challenge the constitutionality of his sentence by applying for postconviction relief. In Missouri, for example, "[a] person convicted of a felony ... [who claims] that the conviction or sentence imposed violates the constitution and laws of [Missouri] or the constitution of the United States ... may seek relief in the sentencing court...,"212 This was the avenue that Christopher

209. See VA. SuP. CT. R. 5:22(b); Atkins v. Commonwealth, 510 S.E.2d 445, 453 (Va. 1999); see also GA. CODE ANN. $§ 17-10-35$ (2008) (delineating the automatic review procedure); Coker v. State, 216 S.E.2d 782, 795-96 (Ga. 1975) (explaining the procedure by which the defendant's death penalty is automatically reviewed by the state supreme court).

210. 217 S.W.3d 207 (Ky. 2006).

211. See id. at 209. A plaintiff requesting such a declaration of rights must follow Kentucky Rule of Civil Procedure 57, which provides that "the right to trial by jury may be demanded under the circumstances." KY. R. CIV. P. 57. But this does not mean that the jury will determine the issue of whether the punishment is unconstitutionally cruel and unusual. See KY. REV. STAT. ANN. $\S 418.040$ (West 2006) (providing that a "plaintiff may ask for a declaration of rights, either alone or with other relief" when an actual controversy exists and that "the court may make a binding declaration of rights, whether or not consequential relief is or could be asked").

212. Mo. Sup. CT. R. 29.15; see also Mo. ANN. Stat. $\$ 547.360$ (West 2002) (codifying almost verbatim the language of Rule 29.15). Súch postconviction review benefits the individualization potential of Eighth Amendment determinations because, as one scholar has explained, it has an "intra-system quality"- "the postconviction judge and the prosecutor defending the postconviction action will be familiar with the state law applicable to the case, and quite likely the facts as well, as state postconviction proceedings are often brought before the same trial court that imposed judgment." Christopher N. Lasch, The Future of Teague Retroactivity, or "Redressability," After Danforth v. Minnesota: Why Lower Courts Should Give Retroactive Effect to New Constitutional Rules of Criminal Procedure in Postconviction Proceedings, 46 AM. CRIM. L. REV. 1, 57 (2009). 
Simmons followed to obtain relief in Roper. ${ }^{213}$ Moreover, a defendant may raise his Eighth Amendment claim in a state or federal habeas corpus petition, as was the case in Ford v. Wainwright, ${ }^{214}$ wherein the Court ultimately concluded that the death penalty was unwarranted due to the offender's mental incapacity. ${ }^{215}$ The avenues for raising Eighth Amendment claims are clearly varied and depend upon the jurisdiction's particular rules and procedures, but they tend to be first raised on appeal or in a separate habeas corpus procedure and are not ordinarily decided at the sentencing stage itself. In fact, in several cases in which defense counsel have tried to raise the issue at sentencing, courts have found this inappropriate. ${ }^{216}$

Due to the different procedures at trial, where obscenity issues are first raised, and on appeal, where Punishments Clause issues are often first raised, a jury is available to decide obscenity issues whereas a jury will often no longer be empaneled by the time that a defendant raises an Eighth Amendment challenge to his sentence. It might be easier to empanel a jury in a habeas case than on appeal, but the use of juries is not common in habeas. ${ }^{217}$ Under the federal habeas statute, for example, it is the court's role to "summarily hear and determine the facts, and dispose of the matter as law and justice require." 118 While the statute "does not preclude the use of an advisory jury pursuant to Fed. Rule Civ. Proc. 39 (c)," ${ }^{, 19}$ Moore's Federal Practice asserts that "advisory juries ... should be restricted ... to the exceptional case where there are peculiar and unique circumstances supporting its use," in part because it would likely delay the proceedings. ${ }^{220}$ Interestingly, when an

213. See State ex rel. Simmons v. Roper, 112 S.W.3d 397, 399 (Mo. 2003) (discussing the procedural posture in the Roper case).

214. See Ford v. Wainwright, 477 U.S. 399, 404 (1986), rev'g Ford v. Wainwright, 752 F.2d 526, 527 (11th Cir. 1985).

215. See Ford, 477 U.S. at 410.

216. See, e.g., Nevarez v. State, 832 S.W.2d 82, 87 (Tex. Ct. App. 1992) (concluding that the lower court did not err in refusing "to charge the jury concerning cruel and unusual punishment" because the defendant's punishment was not unconstitutional); Brooks v. State, 642 S.W.2d 791, 799 (Tex. Ct. Crim. App. 1982) (rejecting the defendant's argument that the trial court erred in refusing to instruct the jury to determine whether the punishment of life imprisonment was unconstitutionally cruel and unusual).

217. See Douglas A. Berman, Making the Framer's Case, and a Modern Case, for Jury Involvement in Habeas Adjudication, 71 OHO ST. L.J. 887, 888 (2010) (stating that "[m]odern habeas review of convictions and sentences involves judges, and judges only, conducting 'judicial inquisitions' and then resolving factual and legal disputes without any jury input," but arguing that "there is no obvious constitutional or statutory impediment to federal judges right now opting to empanel juries to aid" in habeas determinations).

218. 28 U.S.C. $\$ 2243$ (2006); see also Berman, supra note 217, at 888 ("Modern habeas review of convictions and sentences involves judges, and judges only ....").

219. Sigler v. Parker, 396 U.S. 482, $487 \mathrm{n}{ }^{*}$ (1970) (Douglas, J., dissenting).

220. 5 James WM. MoORe et AL., MoORE's Federal. Practice $39-42$ n.19 (2d ed. 1996); 
Eighth Amendment complaint is raised as a 42 U.S.C. $\S 1983$ claim, the question of cruel and unusual punishment is often left to juries to determine. ${ }^{221}$ The same is true with respect to criminal claims under 18 U.S.C. $\S 242$, which is the criminal equivalent to $\S 1983 .{ }^{222}$ This leaves a surprising framework in which many issues of cruel and unusual punishment are decided by judges, but some are actually decided by juries. And there seems to be no problem of unworkability, or even nonuniformity, when this issue is decided by juries as a mixed question of law and fact rather than by judges as pure questions of law.

Overall, this procedural difficulty of the unavailability of a jury in some contexts in which the issue of cruel and unusual punishments is raised should not trump the constitutional salience of the jury to this important question. The fact that the jury's role was central to determinations of cruel and unusual punishment during the Founding Era, the importance of the jury in determining such moral questions, and

see also Sigler, 396 U.S. at 487. Professor Douglas Berman argues, however, that this efficiency argument is no longer valid because "modern federal habeas actions are now anything but efficiently resolved by judges." Berman, supra note 217 , at 911 . Instead, he argues, that juries should be involved in habeas determinations. See generally id.

221. See Pattern Jury Instructions for Cases of Excessive Force in Violation of the Fourth, Eighth and Fourteenth Amendments: For the District Courts of the United States Court of Appeals for the First Circuit $\S 2.1$, (June 4, 2002), available at http://www.med.uscourts.gov/ practices/excessiveforce09jul13.pdf (instructing juries on their determinations of cruel and unusual punishment in the context of excessive force by a corrections officer).

222. See, e.g., United States v. Kulp, No. 97-CR-14, 1997 WL 438834, at *8-9 (E.D. Pa. July 30,1997 ) (discussing jury instructions related to the Eighth Amendment in a $\$ 242$ case). Section 242 provides:

Whoever, under color of any law, statute, ordinance, regulation, or custom, willfully subjects any person in any State, Territory, Commonwealth, Possession, or District to the deprivation of any rights, privileges, or immunities secured or protected by the Constitution or laws of the United States, or to different punishments, pains, or penalties, on account of such person being an alien, or by reason of his color, or race, than are prescribed for the punishment of citizens, shall be fined under this title or imprisoned not more than one year, or both; and if bodily injury results from the acts committed in violation of this section or if such acts include the use, attempted use, or threatened use of a dangerous weapon, explosives, or fire, shall be fined under this title or imprisoned not more than ten years, or both; and if death results from the acts committed in violation of this section or if such acts include kidnapping or an attempt to kidnap, aggravated sexual abuse, or an attempt to commit aggravated sexual abuse, or an attempt to kill, shall be fined under this title, or imprisoned for any term of years or for life, or both, or may be sentenced to death.

18 U.S.C. $\S 242$. 
the jury's capability to closely examine the facts of a case to determine whether the imposed punishment exceeds the bounds of retribution, deterrence, incapacitation, and rehabilitation, are all more important than strictly maintaining the current procedural framework for deciding criminal questions of cruel and unusual punishment. To harness the advantages of allowing juries to decide these constitutional moral questions, courts could empanel special juries to decide them. It would perhaps be more prudent, however, to have issues of cruel and unusual punishment decided in the first instance as part of the penalty or sentencing phase of trial rather than on appeal when juries are ordinarily not readily available. In most capital cases, in which many of these questions of cruel and unusual punishments are raised, courts are required to ask juries whether capital punishment is appropriate. ${ }^{223}$ When juries are thus involved in sentencing criminal offenders, courts could simply allow the defendant's counsel to make Punishments Clause arguments to the jury where appropriate. This is contrary to at least some courts' practice of denying counsel the ability to make such arguments at this stage. ${ }^{224}$ Courts could then instruct jurors on the limits of punishment under the Eighth Amendment. These instructions could broadly direct jurors to ensure, in formulating an appropriate sentence for the offender, that the punishment is not unduly cruel. Alternatively, these instructions could be more narrow to align with the Supreme Court case law on Punishments Clause determinations, as is done when instructing jurors on cruel and unusual punishments pursuant to $\S 1983 .{ }^{225}$ This could be difficult in criminal Punishments Clause determinations, however, because the Court has not clearly articulated relevant factors to consider in determining whether a punishment is unconstitutionally cruel under the Eighth Amendment. ${ }^{226}$ As I have argued elsewhere, though, Eighth Amendment cruelty determinations should be based on factors related to the punisher's motive and the

223. See Nora V. Demleitner et al., Sentencing law and Policy: Cases, Statutes, AND GUIDELINES 254 ( $2 \mathrm{~d}$ ed. 2007) ("Although very few states rely on juries for noncapital sentencing decisions, nearly all states that authorize the death penalty give juries a central role in capital sentencing."); Samuel H. Pillsbury, Fear and Trembling in Criminal Judgment, 7 OHIO ST. J. CRIM. L. 827, 846 (2010) ("[I]t's worth noting that all constitutionally approved systems of capital punishment in the United States provide for jury participation in sentencing, and in most but not all instances, death requires jury approval.").

224. See, e.g., Nevarez v. State, 832 S.W.2d 82, 87 (Tex. Ct. App. 1992) (concluding that the lower court did not err in refusing "to charge the jury concerning cruel and unusual punishment" because the defendant's punishment was not unconstitutional); Brooks v. State, 642 S.W.2d 791, 799 (Tex. Ct. Crim. App. 1982) (rejecting the defendant's argument that the trial court erred in refusing to instruct the jury to determine whether the punishment of life imprisonment was unconstitutionally cruel and unusual).

225. See supra note 103.

226. See Ryan, supra note 26 , at 83. 
nature and quality of the punishment at issue. ${ }^{227}$

In noncapital cases, ${ }^{228}$ it could be more difficult to implement this greater role for the jury in Punishments Clause determinations. A handful of states employ jury sentencing, which would make it just as easy to instruct sentencers on the limitations of punishment as in the capital context. There are good reasons for jurisdictions to engage in jury sentencing ${ }^{229}$ - some of which overlap with the reasons for allowing juries to resolve issues of unconstitutional cruelty-but the overwhelming majority of jurisdictions leave sentencing to judges' discretion. In this context, it might be worth empaneling a jury to ascertain the people's view of the current standards of decency. After all, jury members are more representative of the vicinage in which the crime occurred and are much more likely to be representative of the nation as a whole than are the predominantly well-educated, upper class Caucasion male judges in both the federal and state systems. ${ }^{230}$ Empaneling a jury in this context could take its toll on the jurisdiction's resources and also delay already stagnant proceedings, however. At a minimum, sentencing courts should specifically address questions of unconstitutional cruelty, treating them as mixed questions of law and fact rather than as pure questions of law. By doing so, trial court judges will be empowered to engage closely with the facts in determining the constitutionality punishments and also equip appellate court judges to rule more clearly on these issues rather than making overly broad determinations about the constitutionality punishments.

\section{CONCLUSION}

Juries stand at the heart of our criminal justice system because they act as a bulwark of liberty by protecting individuals from overreaching legislatures and unrepresentative judges. It only makes sense, then, for juries to protect criminal offenders from punishments that society deems unduly cruel. While this is contrary to the commonly accepted understanding that most constitutional questions are purely legal questions to be decided by judges, the Court's First Amendment obscenity jurisprudence demonstrates that juries are just as capable of resolving some constitutional questions. This is especially so when those questions are rooted in society's moral values, as in the

227. See id. at 124,149 . Courts could also inform jurors of, or allow evidence on, how similarly situated offenders have been sentenced, thus allowing jurors to compare sentences in similar cases as judges are able to do.

228. In contrast to capital cases, noncapital cases often do not include juries in sentencing decisions.

229. See generally Iontcheva, supra note 1, at 314 (arguing that jury sentencing is central to implementing democratic rule).

230. See supra notes $67-68$ and accompanying text. 
Punishments Clause context, and when individual facts are important to resolving the questions, as is the case when the details of a crime and a criminal offender's history and personal characteristics are relevant to the determination of the appropriate sentence to impose. Based on the prominence of the jury in the criminal provisions of the Bill of Rights and the fact that criminal law is primarily a matter of local concern, one could argue that juries should be resolving many, if not all, constitutional questions that arise in the criminal context. For example, a jury may be better equipped to determine whether a Fourth Amendment search is "reasonable" or whether police officers used unconstitutionally coercive force, that runs afoul of the Fifth Amendment, to extract a confession. Again, these standards are rooted in society's value judgments. But Eighth Amendment determinations of cruel and unusual punishment are even more firmly grounded in society's mores, and the history of the Punishments Clause emphasizes the jury's importance to these decisions. In the tradition of Apprendi and Booker, it is important to rethink whether our recent practice of leaving these findings to judges rather than juries is constitutionally appropriate. 